\title{
The Reflection of Collective Memory in Architectural Studies
}

\author{
Mahdi Soltani* \\ Assistant Professor, Faculty of Art and Architecture, University of Bonab, Bonab, Iran.
} (Received 5 Sept 2020, Accepted 10 Dec 2020)

Today, interdisciplinary studies have found an important place in the literature of architectural studies. One of the new concepts in the field of historiography and social sciences is "collective memory." This concept was first discussed in detail by Maurice Halbwachs and later described and interpreted by other scholars in various scientific fields. Collective memories are events experienced by individuals in a social framework and in interaction with the group. The reminder of these memories occurs using the mechanism of association of meanings and through objects, individuals, places and similar experiences, and in other words, collective memory means a shared memory with a group or society. The collective memory has differences and similarities with history and is tied to the concepts of identity and social belonging, and also has a connection to the concept of place. Although the experience of a place occurs individually, the shared experiences resulting from social categories and individual characteristics resulting from these categories ultimately lead to the receiving, storage and recording of these receives within the framework of shared social memories. In this article, by recognizing the different aspects of the concept of collective memory and its relationship with different areas of architectural studies, the quality of its use in architectural studies is examined, and some resources for this study are suggested. Accordingly, different texts have been explored by the interpretive method of study and by logical reasoning, and the relationship between this concept and different fields of study has been proposed. This concept can be used in various stages of architectural studies such as studying religious buildings, creating memories in places, design- ing monumental spaces and studying the design of urban spaces. The relationship between this concept and architecture can be searched through sources such as written, visual, and oral sources. Informal written sources are more honest and reliable in understanding collective memories related to architecture, and examining them critically can open valuable windows to understanding collective memories. Oral mediators of memories are also valuable resources that are somewhat immune to deliberate distortion. These oral sources can include the collective memories of ordinary people, technicians and builders of architectural works, the words of other witnesses and users of works, and the like. Collective memories can also be studied as an important and valuable part of the place and architectural works. The presence of collective memories in cities strengthens the sense of identity and belonging to the city. Collective memories are the main aspect of the study in some architectural works such as monuments. The continuity of life in religious buildings is closely related to the preservation and strengthening of collective memories, and also the life of public spaces and the extent to which people belong to them are correlated with the presence and continuity of collective memories. Different aspects of this concept can be identified and applied in different areas of architectural study. Collective memories at different stages of the development of human societies are recorded and stored in various sources. These sources can assist the researcher in such a study.

Keywords: Collective Memory, Architectural Studies, Place, Identity, Belonging Sense.

*Corresponding author. E-mail: mahdisoltani@ubonab.ac.ir

Copyright(C) 2020, the Authors / This open-access article is published under the terms of the Creative Commons AttributionNonCommercial 4.0 International License which permits Share (copy and redistribute the material in any medium or format) and Adapt (remix, transform, and build upon the material) under the Attribution-NonCommercial .terms 


\section{باز تاب مفهوم خاطره جمعى در تاريخنكارى معمارى}

\section{مهدى سلطانى"}

استاديار دانشكده هنر و معمارى دانشكاه بناب، بناب، ايران.

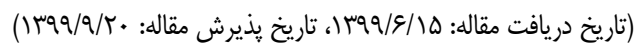

امروزه مطالعات ميان رشتهاى جايگاه مهمى در ادبيات مطالعات معمارى يافتهاست. يكى از مفاهيم جديد مطرح شده

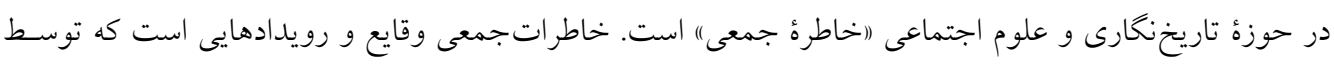

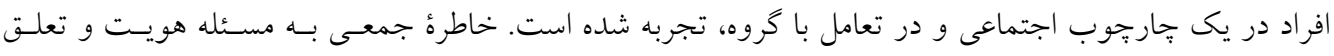

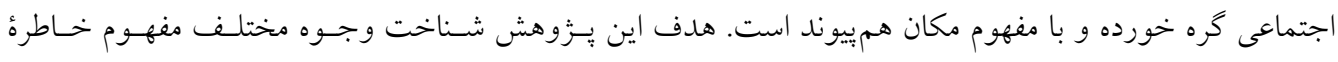

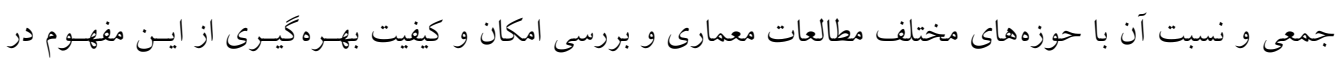
تاريخنخارى معمارى است. براين اساس، متون مختلف با روش تفسيرى مطالعهُ اكتشافى شده و با اسـتدلال منطقى،

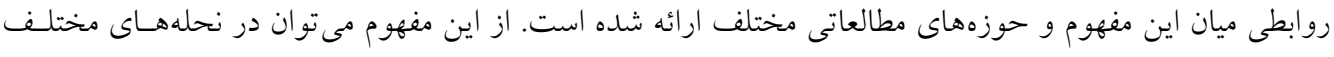

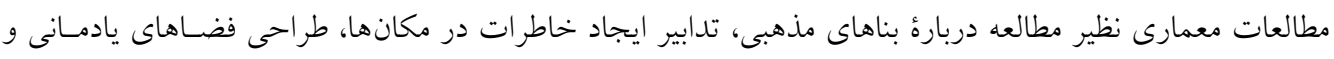

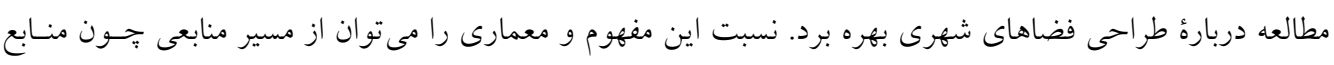

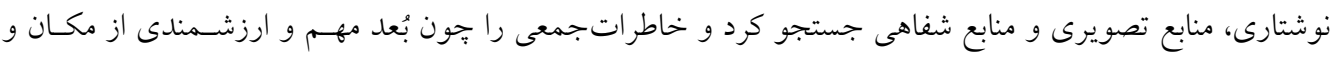

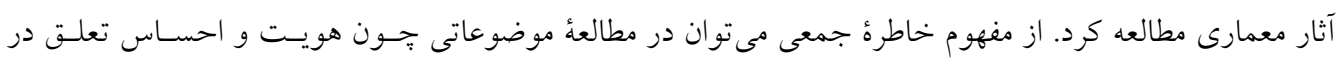

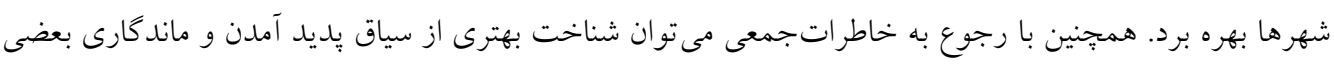

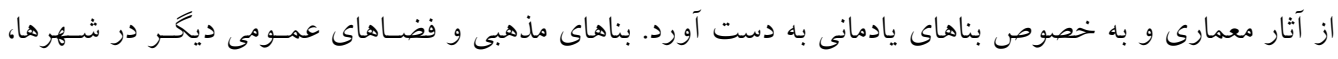

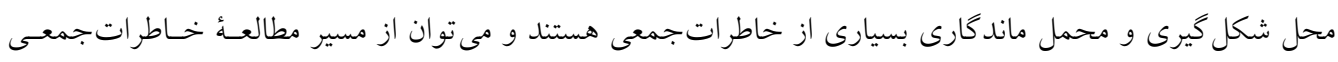

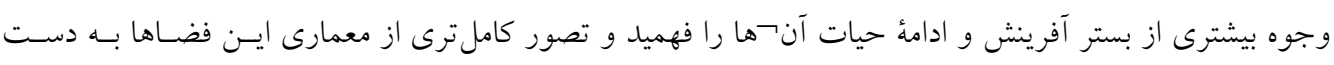

خاطرة جمعى، مطالعات معمارى، تاريخنخارى، هويت و احساس تعلق. 
مى توان از خاطراتجمعى مرتبط و منـدرج در آثـار كَذشتها،

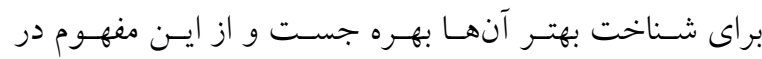

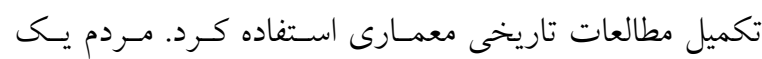

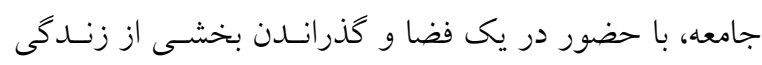

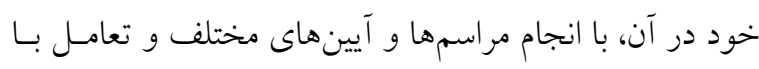

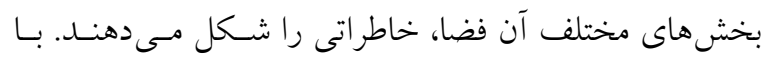

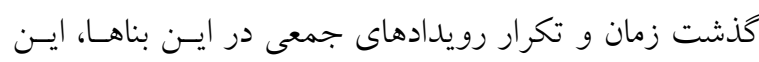

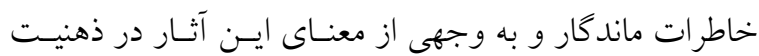

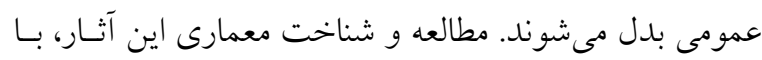

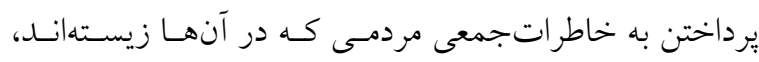

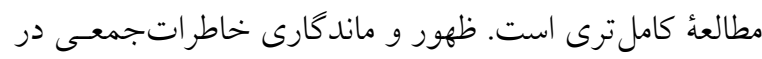

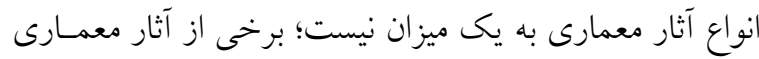

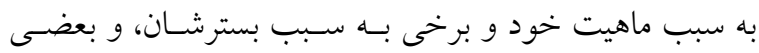

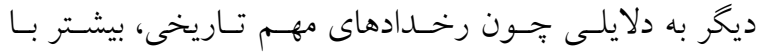
خاطراتجمعى گره خوردهاند و يرداختن به خاطرةْجمعى در

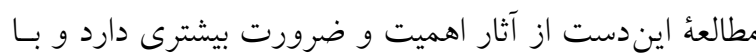

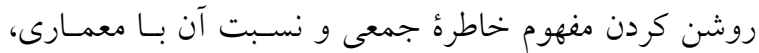

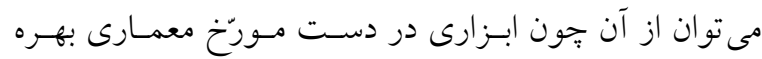
جست.

2009). سرورى و رحيمزاده نقش و جايخاه خـاطراتجمعى

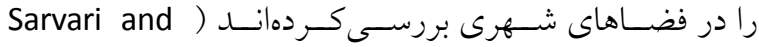
Rahimzadeh Nasakhi 2015 و نادرى و همكار انش حافظـــ

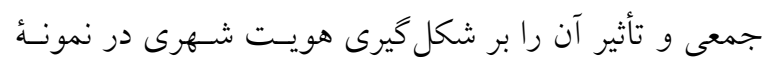

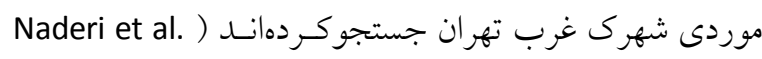
2019). اسـمعيليان و رنجبـر در يـك بررسـى تطبيقىى، بــه

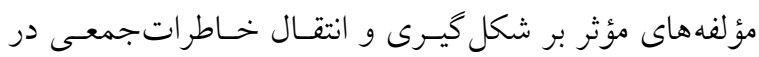

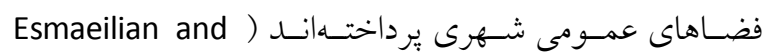

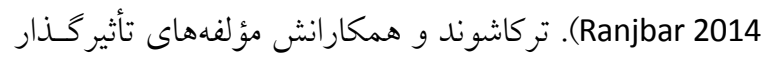

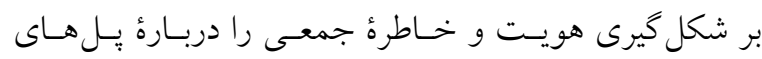
تـاريخى بازشناسى كـردهانـد (Tarkashvand et al. 2017) .
مفهوم ("خاطرة جمعىى"' در مطالعات مرتبط بـا زمـان و مكـان

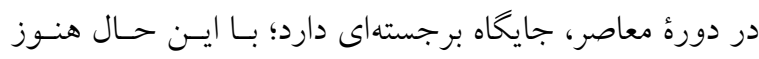
بدنهاى كسترده از ادبيات موضوعى اختصاصى، دربارة ارتبـاط

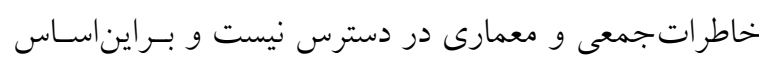

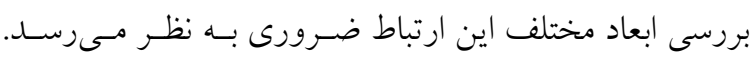

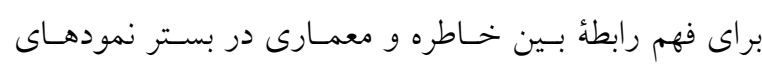

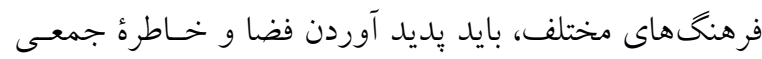
بررسى شود. خاطرات در زمان جارى هستند؛ اما نبايــــ آنهـا را به صورت خطّى تصور كرد. خاطره در زمان كذشته، حسال

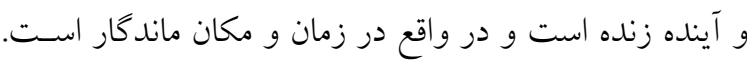
خاطرات كاه ارزشهايى هستند كه روابط و نيازهـا را آثـكار

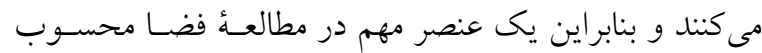
مىشوند. خاطرات به حس زمان و حس فضا مرتبط هستند،

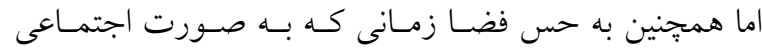

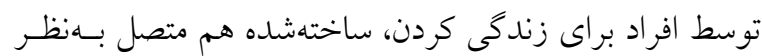

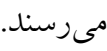
بخش مهمسى از مطالعـات معمـارى بـه جايخـاه آثـار در

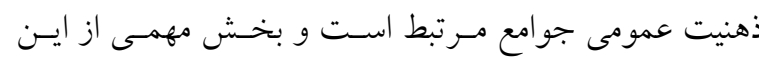

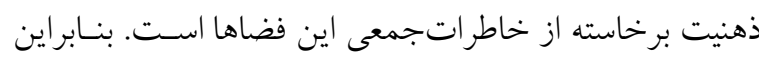

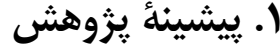

با ورود مفهوم خاطرة جمعى بـه ادبيـات مطالعـات معمـارى،

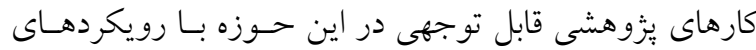

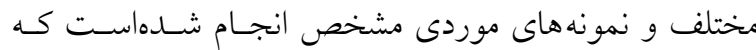

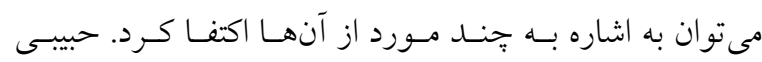

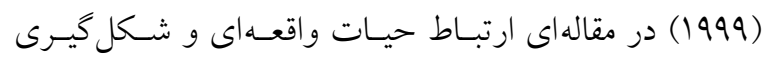

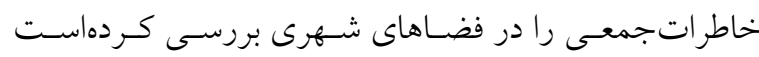

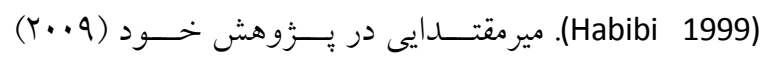

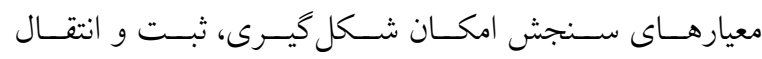

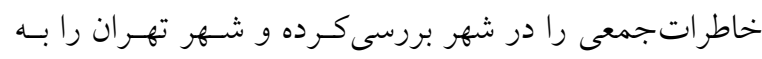
عنوان نمونهُ موردى مطالعه كـردهاسـت ( Mirmoghtadaee 
بازتاب مفهوم خاطره جمعى در تاريخنخارى معمارى

معنى ندارد (Habibi 1999). در تعريف خاطرهُ جمعى مىتوان كفت، خاطراتجمعى وقايع و رويدادهايى هستند كه توسـط افراد در يك جارجوب اجتماعى و در تعامل با حـروه تجربـه

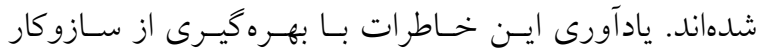
تداعى معانى و به واسطةُ اشيا، افراد، مكـانهـا و تجربـهـهـاى مشابه رخ مى دهل و به عبارتى خاطره جمعى به معنى خـاطره مشترك با گـروه يـا جامعـه اسـت (Lewicka 2008). مفهـوم (اخــاطره) از زمـان يونـان باسـتان مـورد توجــه انديشـمندان فيلسوف و جامعهشناس بودهاست. باين حـال در اواخـر قـرن نوزدهم و او ايل قرن بيستم بود كه توجه به خاطرات به عنوان

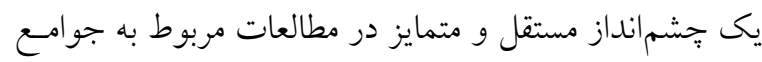
انسانى مطرح شد. شايد اولين كاربرد واضح اصطلاح خـاطرة

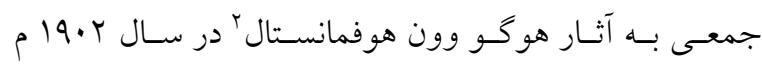
بازگردد (Olick and Robbins 1998). زمانى كه او از لايههاى

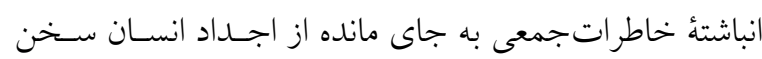

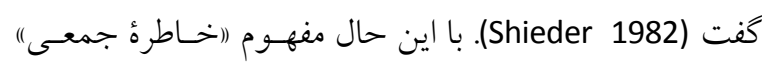
اولين بار بهوسيلة جامعهشناس فرانسوى هـالبو اكس بـ (NVV)

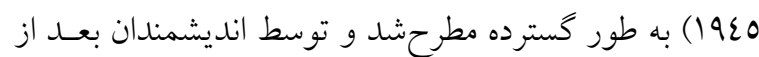
او و با تكيه بر آرايش توسعهيافت.

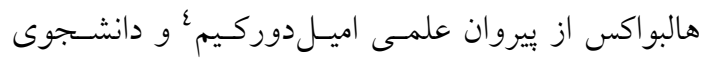
هنرى بركسن ْ بود. اولين رساله مفصل وى درباره خـاطره در

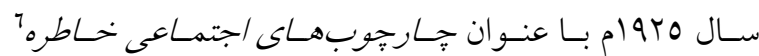
متتشرشد كه مطالعات قبلى او بر نظرية (انمودهاى اجتمـاعى)" v. دوركيم را با تحقيـق متـأخرش دربـارهُ طبقـــ كـارگر مـرتبط مىكرد. در اع 19 ام. دومين كتاب هالبواكس دربارهُ خـاطره بـا عنوان تويوكر/فى /فسانهاى سرزمين مقاس 1 منتشر شد كـه در واقع بِاسخى به بعضى از ايرادهاى دوركـيم دربـارهُ نظريسه او

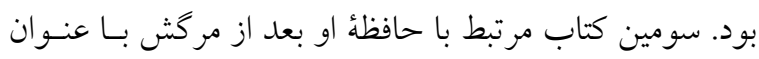

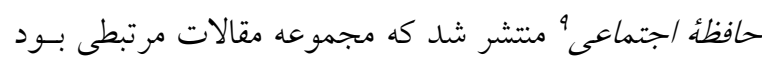

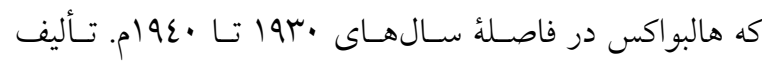
كردهبود (K.Olick et al. 2011). همزمان با انتشـار ايسن آثـار،

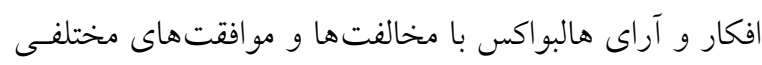
از سوى انديشمندان هم عصرش روبه رو شد؛ اما اين آثـار بـهـ

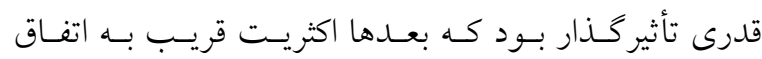

عنانهاد و همكارانش نقش خاطره جمعى را در فرايند احيـاى

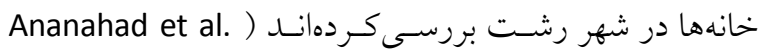
2019). حسنى ميانرودى و همكــارانش بـهـ واكـاوى مفهـوم خاطره جمعى با رويكرد نشانهشناسى در ميـدان حسـن آبـاد تهران برداختهاند (Hasani Mianroudi et al. 2018).

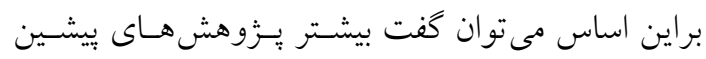
نحوه شكل گيـرى خـاطرات جمعسى را در نمونسهـــاى مـورد

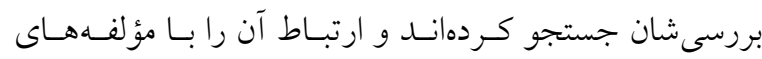

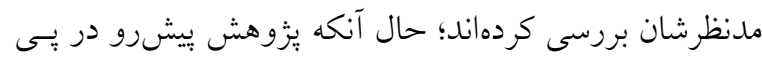

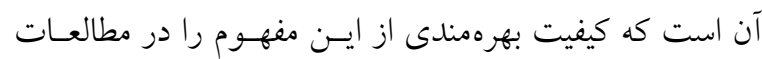

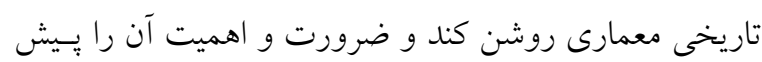

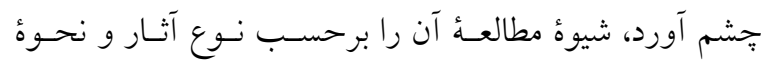
حضور خاطراتجمعى در آنها مشخص كند.

\section{r. (روش يزوهش}

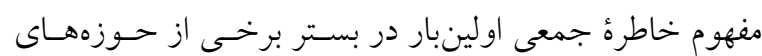
علوم انسانى جون تاريخنخارى و جامعهشناسى مطرح شد. در اين بزّوهش، با رجوع به متونى اصلى كه اين مفهوم در آنهـا تدوين شده، وجوه مختلف آن شـناخته شــه و نسـبت آن بـا برخى از حوزههاى مرتبط با معمارى روشـن شــه اسـت. بـا روشن شدن اين نسبت، كيفيت بهرهيـرى از ايسن مفهـوم بـر مبناى مراحل شكل گيرى و ثبت آن، در مطالعه تاريخ معمارى بررسى شده است. بر اين مبنا متون مختلف با روش تفسيرى، مطالعهُ اكتشافى شدهاند و با استدلال منطقى روابطىى جديــ ميان اين مفهوم و حوزههاى مختلف مطالعات معمارى مطرح شده است. در امتداد اين مسير، يّ از روشن شدن مفــاهيم و تعاريف اصلى و تشخيص نسبت مكان و خاطره جمعسى، بـه بازتـاب خـاطره جمعسى در شـاخههـاى مختلـف مطالعـات معمارى يرداخته شدهاست.

\section{س. خاطره جمعى و وجوه مختلف آن}

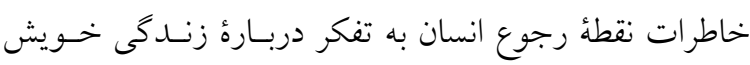
هستند. محدودة زندگى انسان با شـكل گحرفتن خـاطرات در ذهن او تعريف شده است و البته خـاطره بـدون واقعسه اثـر و

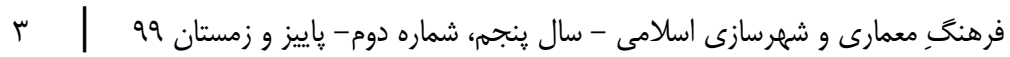


است كه ييشتر ارتباط آنها با معمـارى، توسـط انديشـمندان

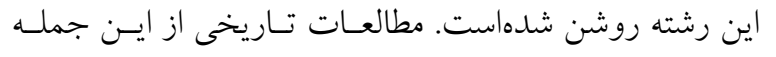

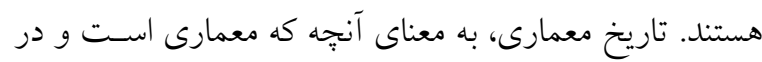

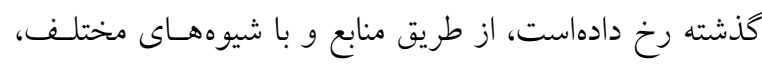

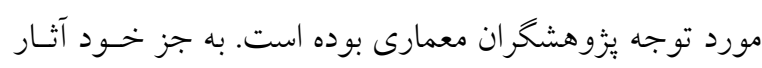

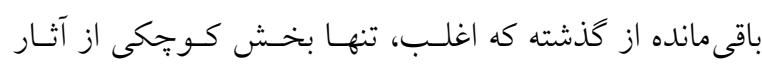

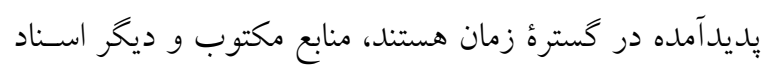

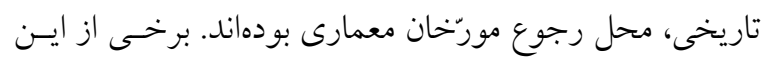

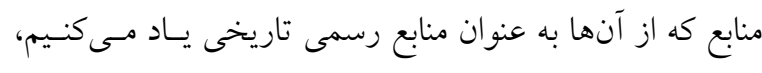

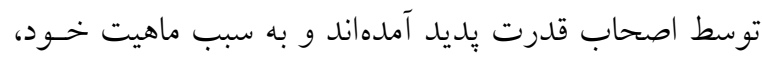

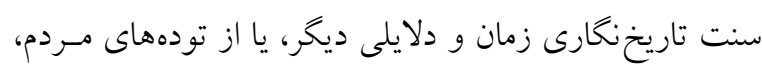

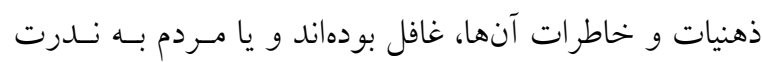

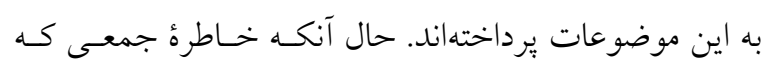

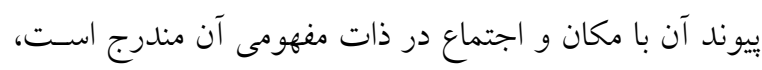

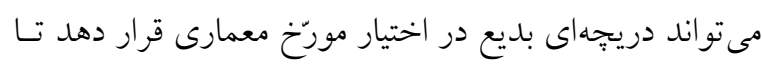

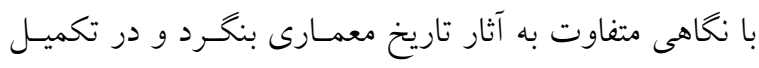

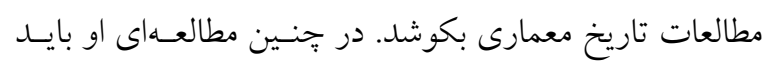

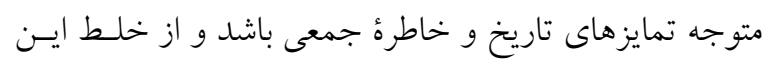

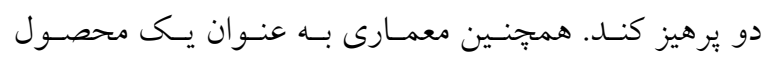

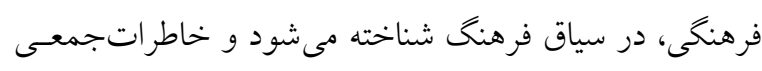

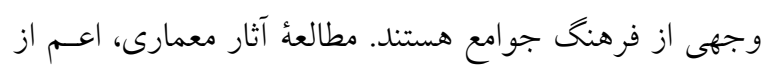

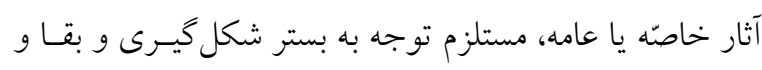

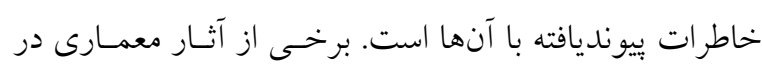

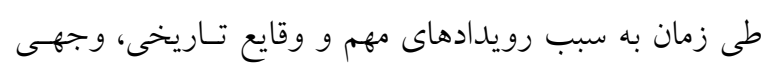

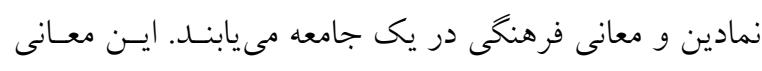

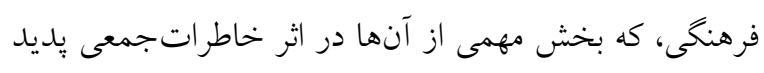

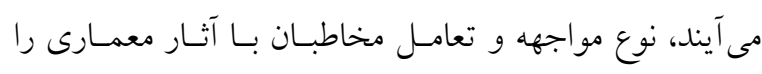

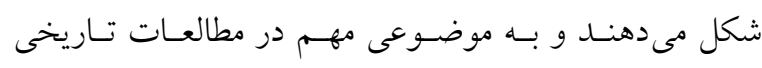

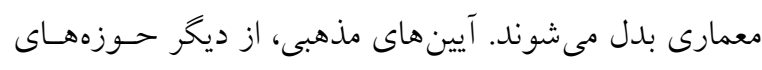

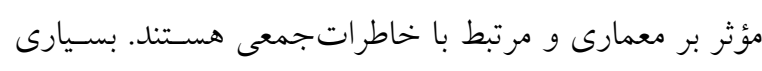

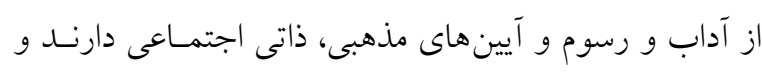

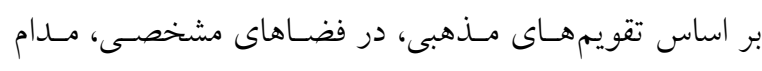

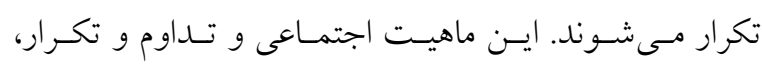

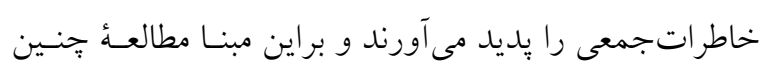

مطالعات درباره خاطرة جمعى با رجوع به آثار او ييشرفت.

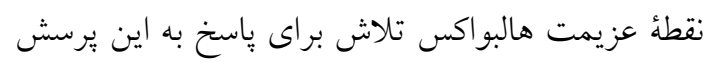

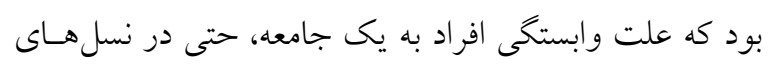

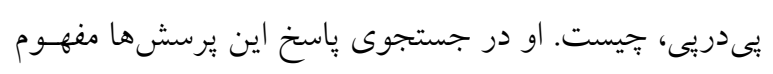

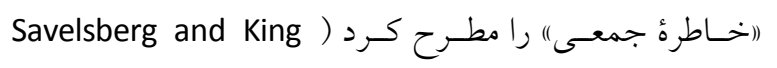

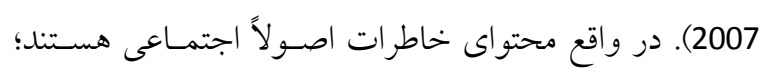

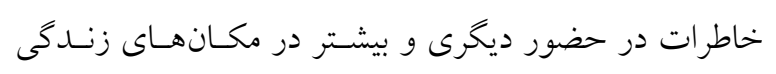

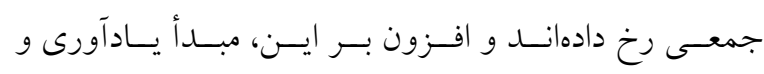
كرامى داشت خاطر ات اغلب جنبه اجتماعى دارد ) Paez et al.

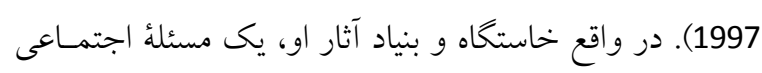

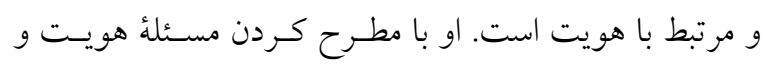

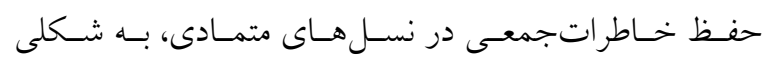

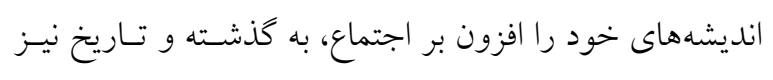
مرتبط كرد. بنيان اصلى نظرية هالبو اكس درباره خاطرةججمعى سه بُعد

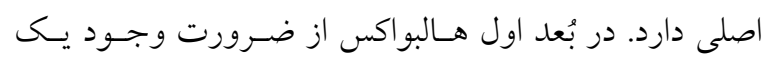

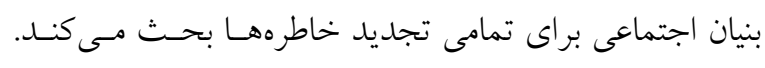

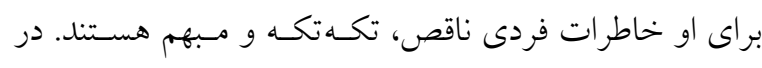

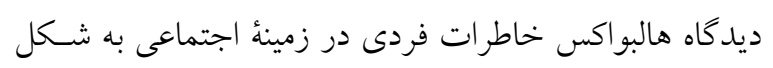

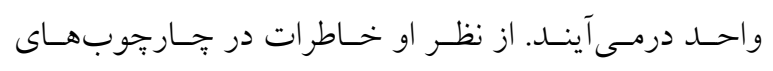

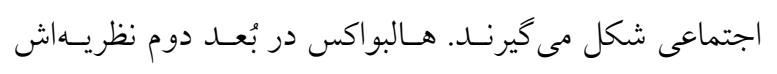

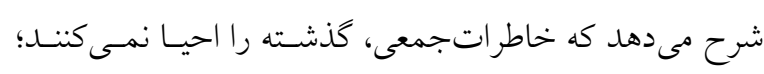

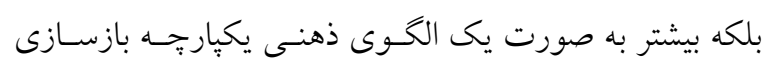

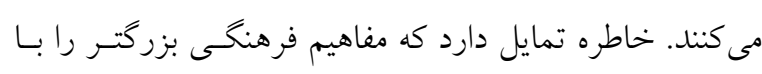

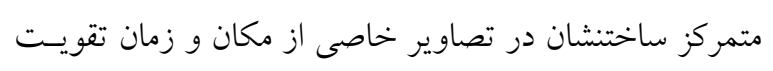

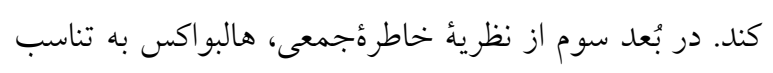

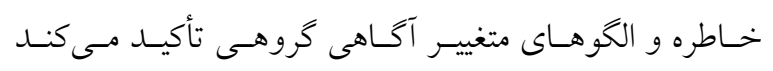

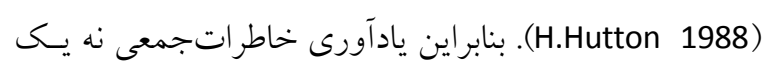

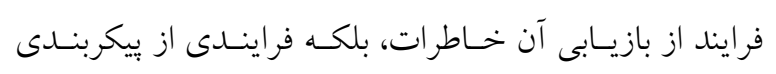

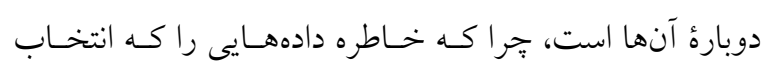

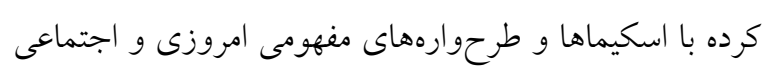
اش تطابق مى بدهد.

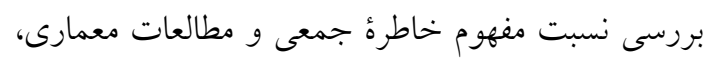

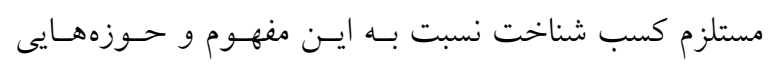




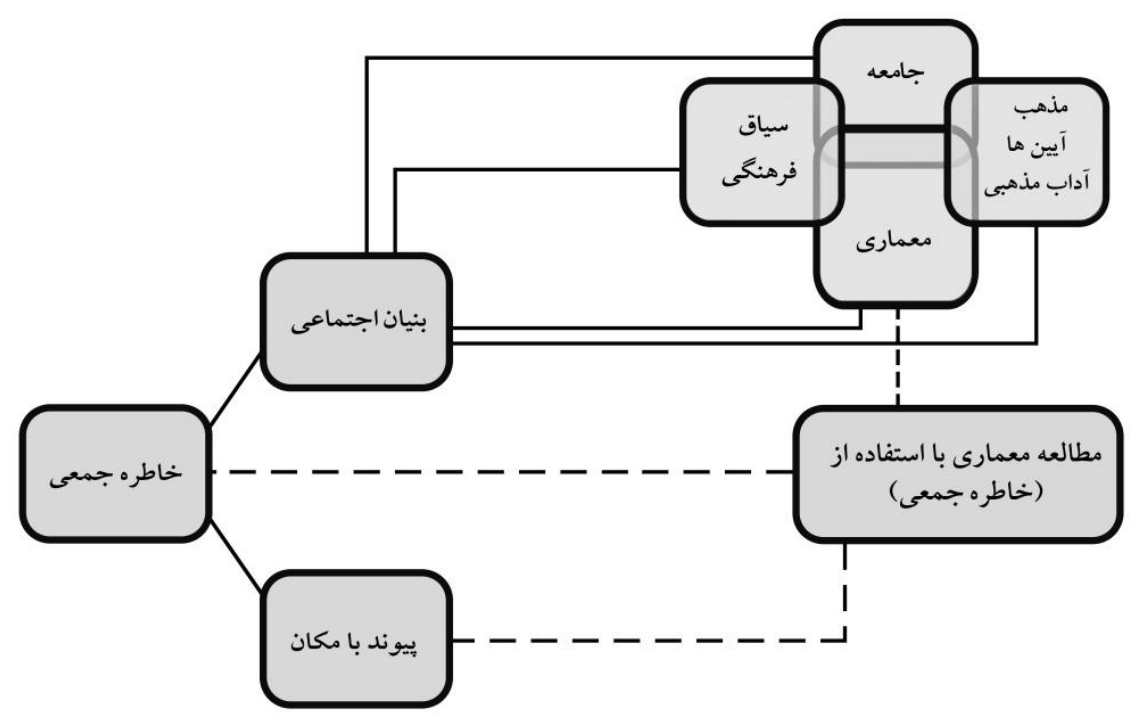

تصوير ا: نمودار نسبت مطالعُ خاطرئ جمعى و حوزهایى مجاور

Fig. 1: Collective memories in the public spaces

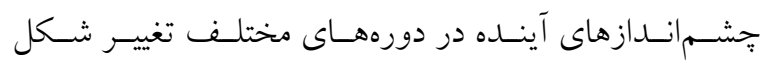

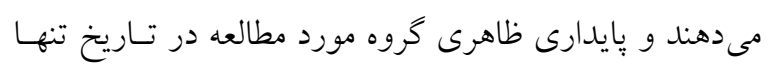
به دليل بايدارى طبقهبندى هاى بيرونى مانند مكانها و نـامهـا

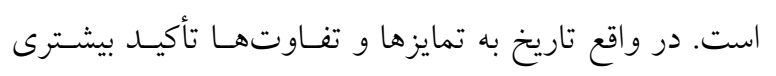

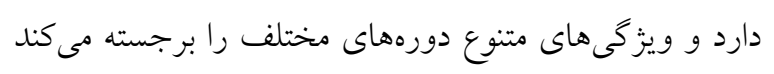

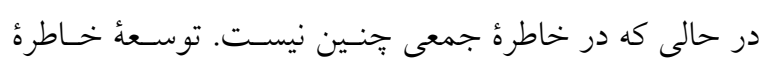

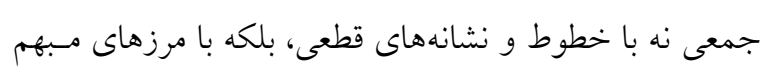

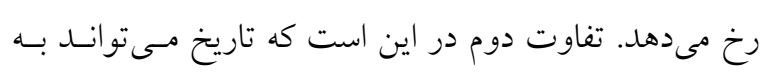

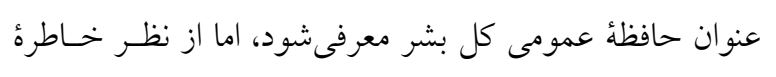

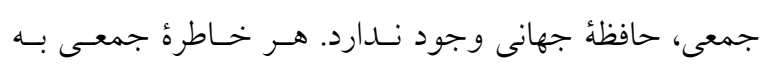

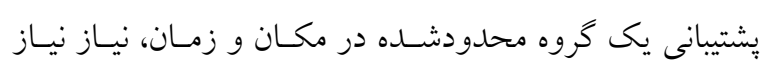

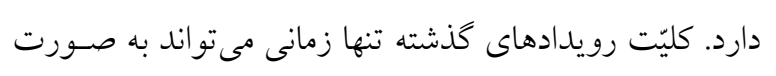

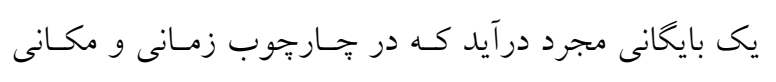

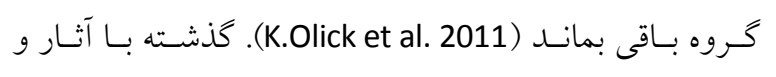
ارزش هاى اجتماعىاش، همجنــان در زمـان حاضـر، حضـور

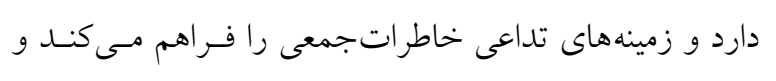

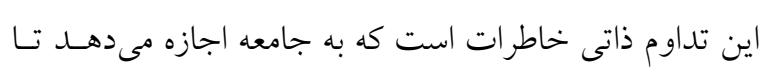

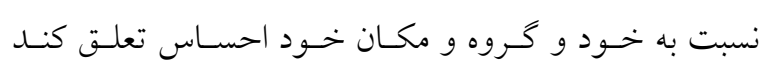

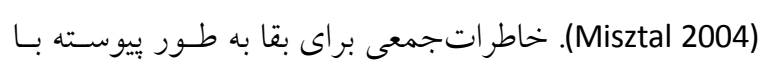
هدف ساز ارارى با وضعيت تاريخى زمان خود تغيير مى يابنـا،

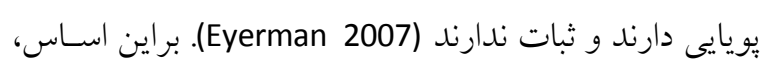
تاريخ و خاطره، هر دو بخشى از دانستها و يافتهاى ما را ار از
آثارى هم مستلزم توجه به مفهوم خاطر اتجمعى ييوند

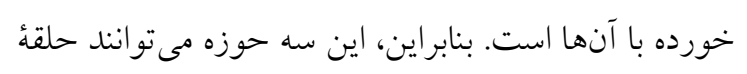

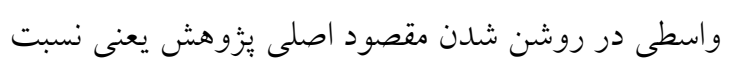

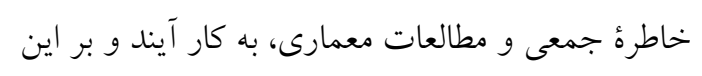
اساس در ادامه به آنها يرداخته شده است (تصوير ()).

\section{"-1. خاطرة جمعى و تاريخ}

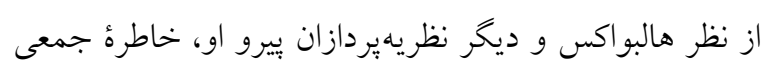

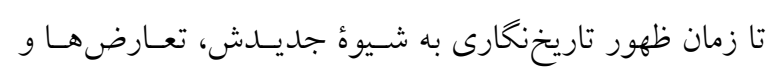

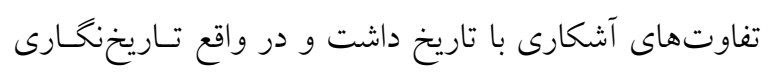

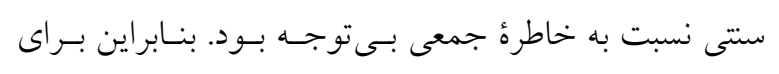

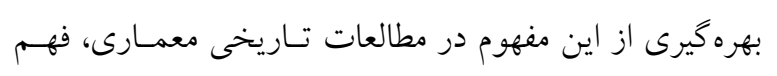

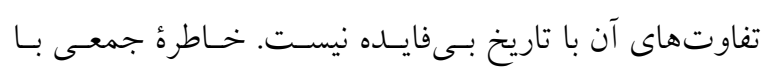

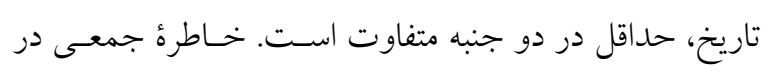

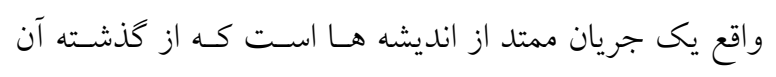

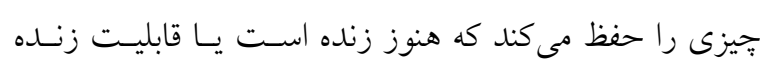

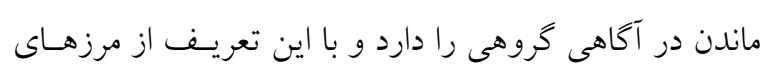

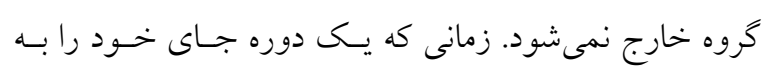

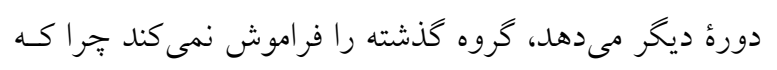

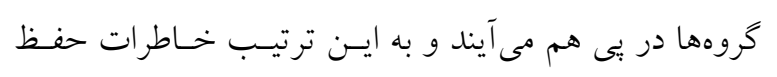

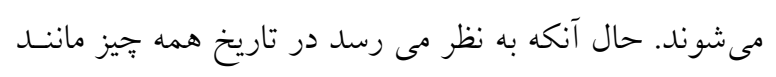

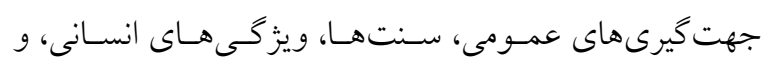


است. به اينترتيب حافظئ فرهنگى با قابليت عينيت بخشـيدن به هويت و توانايى در بازسازى خاطراتجمعى و بــا يريـايى مراسمها، آيينها و جشنها و بريايى يادمانهـا، ويزگكى هـاى

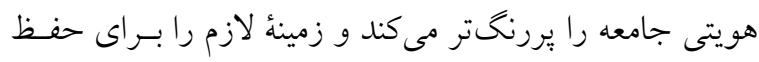
خاطرات و فرهنخ كذشته به صورت عينى فراهم مى آورد.

\section{ب-r. خاطرهُ جمعى، مذهب و آيينها}

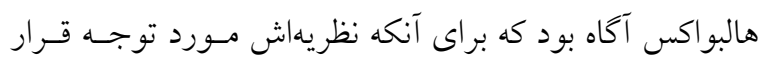

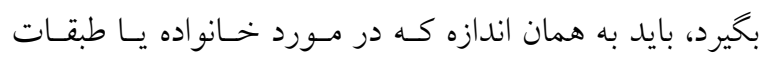
اجتماعى قابل اعمال است، در مورد نهادى مانــــ اديـان و بــه

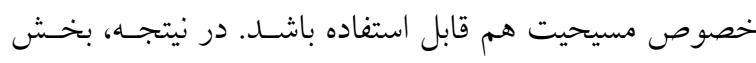
قابل توجهى از نظريذٔ او صريحاً به اين موضوع يرداخته است (Burkett 2009). حافظهُ خاطرات مذهبى كاه تلاش مسىكنــ كه خودش را از جامعهُ روزمره ايزولـه كنــ، بـا ايسن حـال از همان قوانين حافظهُ جمعى بيروى مسىكنـ (Huang 2018) . بنابراين كذشته را حفظ نمى كند بلكه آن را با كمك سنتهــا،

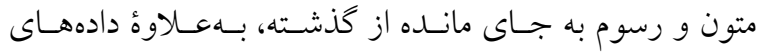
روانشناسى و جامعهشناسى اخير بازسازى مى كند ( Urbaniak

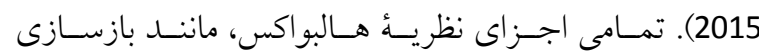

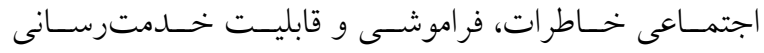

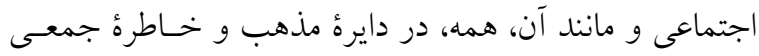
مـذهبى حاضـر هستـند همـانطور كـه در سـاير حـوزههـاى تعامل هاى اجتماعى حاضر هستند (Carpenedo 2017) ـ البته بايد دقت كرد كه ميزان اجتماعى بودن ماهيت اديان و مذاهب متفاوت است. با اين حال در اكثريت اديان، بركزارى آيـينهـا

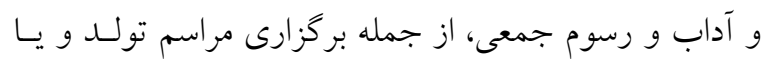

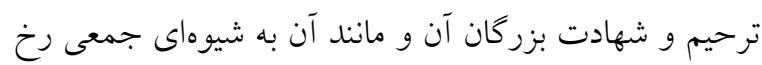

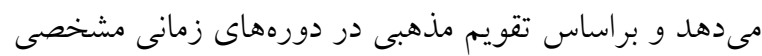
تكرار مى شود. همين تكرار و تداوم به شكل گيسرى و ثبـت و و ماند گارى خاطراتجمعى مذهبى مختلف منجر مىشود.

\section{ع. مراحل شكل كيرى و ثبت خاطراتجمعى}

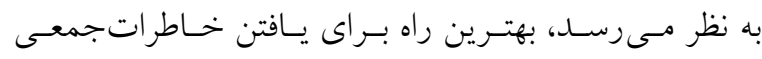

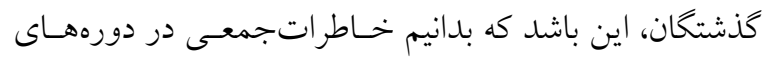

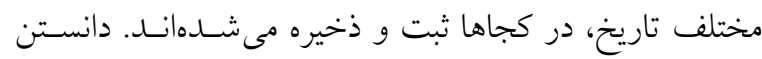

كذشته روايت مى كنند. باين حال روايت ايسن دو از كذشـته، تمايزهايى مشخص دارد. مبناى يك روايت تاريخى، نقل يك رويداد به صورتى است كه اتفاق افتـاده اسـت؛ درحسالى كـه خاطراتجمعسى، كيفيـت ثبـت و ضـبط رويــادها در اذهـان

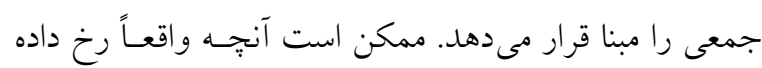
است، با آنجه كه در خاطراتجمعى ضبط شدهاست، تفـاوت

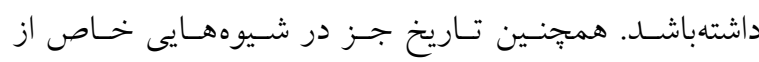
تاريخنخارى، مانند تاريخ اجتماعى يا تاريخ فرهنخى، مـاهيتى

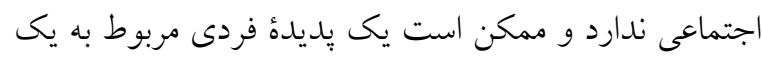
شخص برجسته تاريخى، به موضوعى مهم در بستر مطالعـات

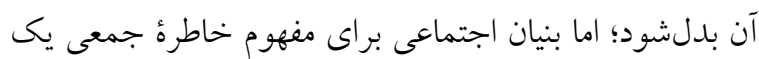

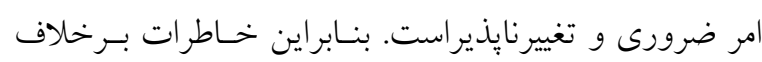

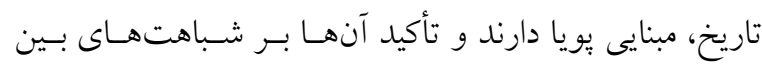

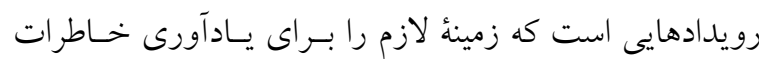

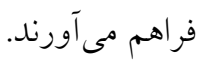

\section{س-r. خاطرة جمعى، هويت و فرهنَ}

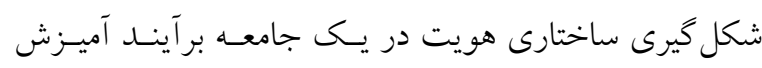
عوامل عينى و ذهنى در خـاطرة قـومى آن جامعـه اسـت. بـهـ

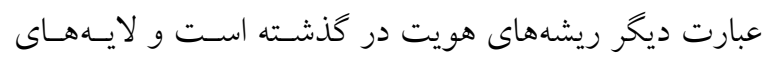
عميق تر هويت با عميق تـر شـــن در ايــن ريشـهـهـا، شــاخته مىشود. بخـش مهمسى از هويست مـردم را خـاطراتجمعسى

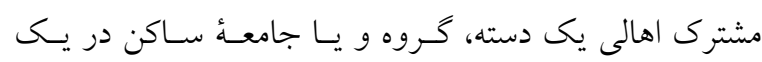

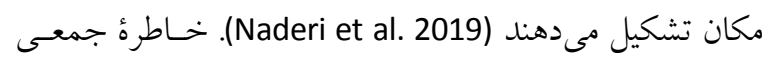
مجموعهاى از تداعىهايى هستند كه جون رواياتى در جامعسه وجود دارند و حفـظ مسىشـوند و احسـاس بيوسـتخى ميـان اعضـاى يـك جامعـهـ را بـهـ وجــود مسى آورنســ و كـاركردى

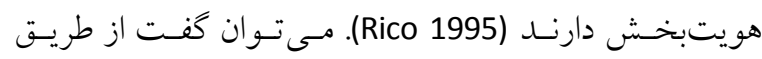
خاطره و حافظـهُ جمعسى اسـت كـه عوامـل سـازندة هويست

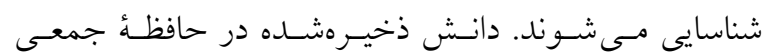
فرهنكى با تمايز صريح نسبت به افراد بيرونى به كسانى كه به آن فرهنگ تعلق دارند، عرضه مىشود و به اين ترتيب به نيـاز به داشتن هويت يُاسخ مى دهد (Assmann1995). اساس كـار حافظهُ فرهنكى بر بازسازى خاطرات است و به همـين دليـل ست كه دانش آن در شرايط واقعى و معاصر معتبـر و مقبـول بـ مبرل 
تصويرهاى متحرى را در كنار منابع نوشتارى در اختيـار جريانهاى ثبت خاطراتجمعى قرار داد.

بر مبناى اين مراحـل، و نحــوة ثبـت و ضـبط خــاطرات

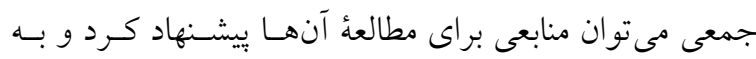
ابعاد مختلف آنها برداخت.

\section{ع-1. منابع مكتوب}

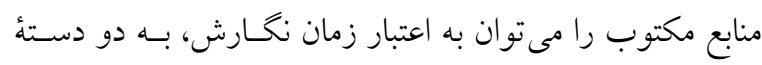
منابع درجه اول كه در زمان رخداد و يا شكل گيـرى خـاطره

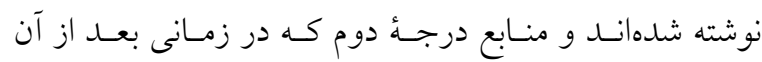
نوشته شدهاند، دستهبندى كرد (Qayyumi 2009). هم:حنين به

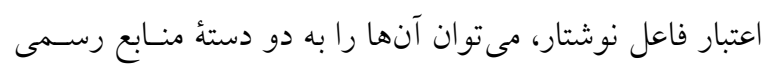

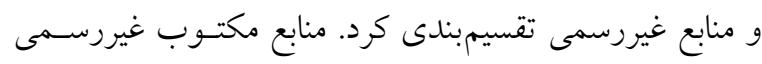
در جهت فهم خاطراتجمعى مرتبط با معمارى، صسادقتـر و

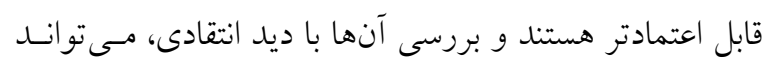

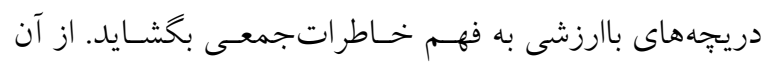

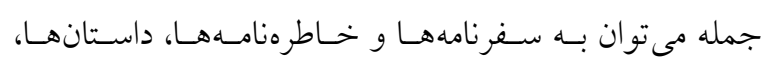
حكايات و افسانهها، فتوت نامهها، بندنامهها و مناقـبنامـههــا

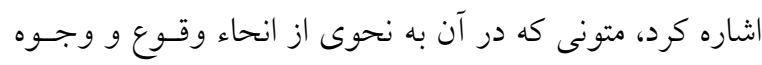
مختلف يك خاطره جمعى ثبت و ضبط شده است.

\section{ع-r. (1) منابع تصويرى}

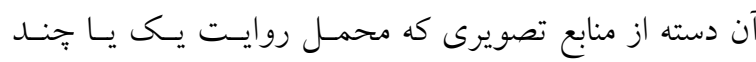

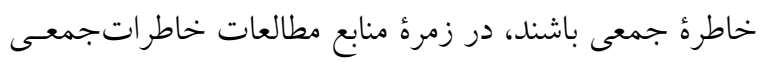
دربارهُ معمارى قرار دارند. از اين دسته مىتوان منـابعى جـــون

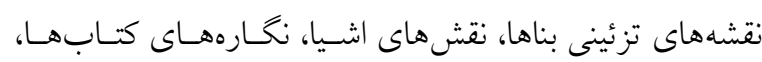

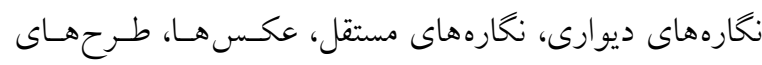

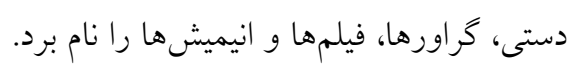

\section{ع-"r. منابع شفاهى}

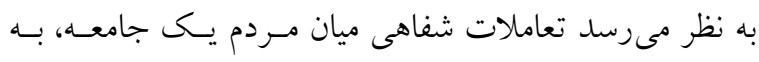

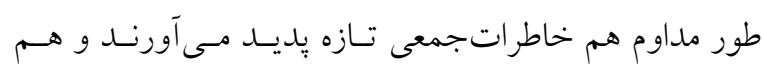
منجر به حفظ خاطرات كذشته مىشـوند. دولـتهـا و ديخـر نهادهاى قدرت كه با ابزارهاى رسمى خود در طول تاريخ در
اين محمل هاى ثبت و ذخيره خـاطراتجمعسى، مسـير يـافتن منابع را براى محقق اين حوزه كوتاهتر و آسانتر خواهد كـرد. زاك لو گاف 'ا مورّخ مشهور فرانسـوى و از بزركـان جريـان

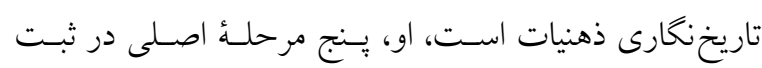

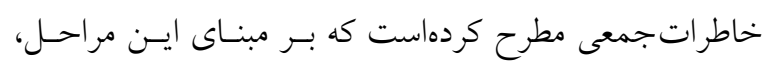

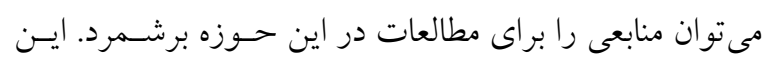
مراحل از ديدگاه لو گاف جنين هستند (Le Goff 1992): - - مرحلة اول به دورهُ تاريخى اشاره دارد كه مردم قـادر بـهـ نوشتن نبودند. لو كاف خاطرات ايسن دسـته را خـاطرات

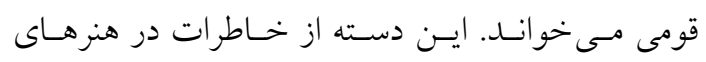

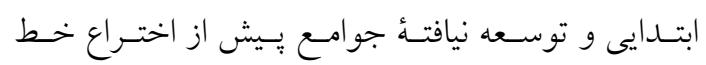
مندرج هستند.

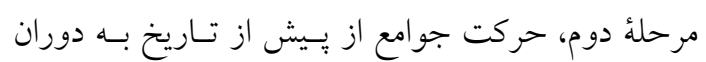
باستان را شامل مى شود كه در آن بعضى از منابع شفاهى خاطرات، به نوشتار بدل مىشوند؛ نوشـتارهايى كـه گـاه

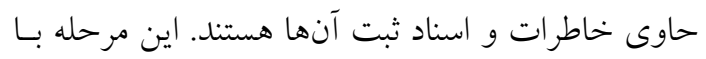
ظهور ساختارهاى شهرى همراه است. مرحلة سوم، خاطرات قرون وسـطا، اعــم از خـاطرات و حكايات و روايات جهان مسـيحيت را شـامل اسـت. در اين دوران، خاطراتجمعى بيشـتر خـاطرات قديسـان و بزركان مــهبى در ارتبـاط بـا جامعسه بـوده و در بسـتر

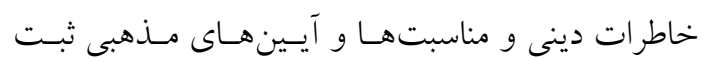
شدهاند.

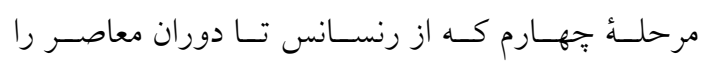
دربرمى گيرد كه در آن با توسعة صـنعت جــابٍ و تـداوم روال خاطرهنويسى، منـابع بيشـترى در اختيـار آينـدكان

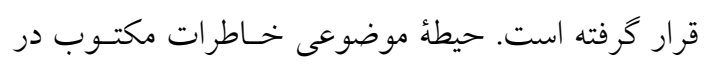

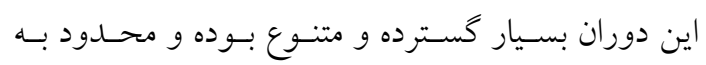
مناسبات مذهبى و آيينى نبوده است.

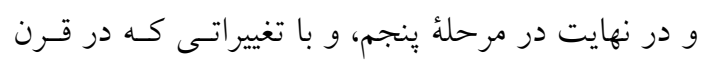
بيستم رخ داد، تحوّلى انقلابى در زمينـة ثبـت خهـاطرات

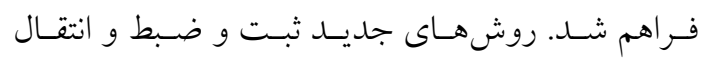
اطلاعات كه از طريق بيشرفتهاى حـوزه الكترونيـى و

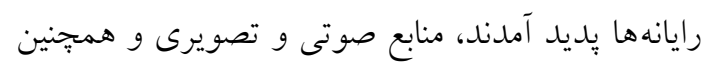


جدول (: ديدكاه انديشمندان دربارة نسبت مكان و خاطرة جمعى (منبع: نغارنده بر اساس منابع مندرج در جدول)

Table1: Scholars views about collective memory and place

\begin{tabular}{|c|c|}
\hline ديد ماه & 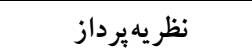 \\
\hline 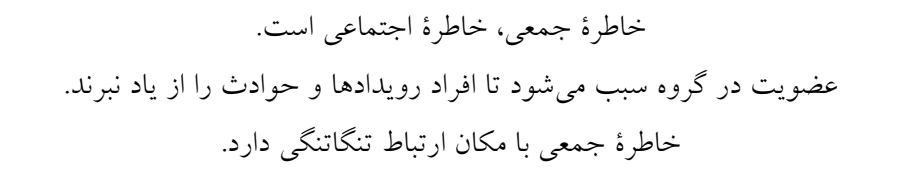 & $\begin{array}{c}\text { مائوريس هالبو اكس (199 (19) } \\
\text { ماكس }\end{array}$ \\
\hline خاطرة جمعى با مكانهاى خاطرهانكيز و با اشياى آنها بيوند ناكسستنى و مهمى دارد. & آلدو روسى (19Ar) \\
\hline ماهيت بشر و مكان با يكديكر گره خوردهاند. & نوربرى شولتز (1911) \\
\hline
\end{tabular}

ساكن هستند، تنها زمانى باقى مى مانند كه در همـاهنكى و در

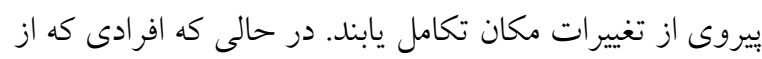

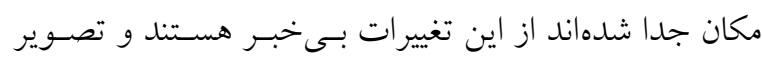

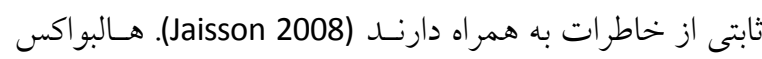
مىنويسد: (آنها نمودى سمبوليك از آن مكان مى سازند. افكار سمبوليك اين خاطرات را از مكان رخدادشان جدا مى كنتـد و و

تنها با باورهاى كروه همر اه مى كنند) (Halbwachs 1992).

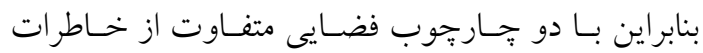
جمعى سروكار داريم. در جارجوب اول، خاطرات بـا شــايط تصويرى ساخته شده از اشيا، خانهها، خيابانها و سـنخهـا و و

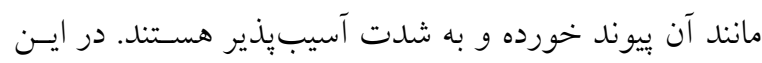
جارجوب مكان و در نتيجـه خـاطرات در معسرض تغييـرات اجتنابنايذير و حتى نابودى قرار دارند. دومين جارجّوب بــــ

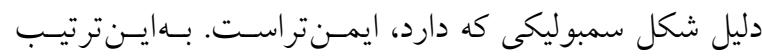
تصـوير يـك خيابـان نزديـك در معـرض تغييـر، در ذهـنـ آشناتراست، اما فقط يك تصوير است و تصـوير يـك يادمـان دور كمتر آشنا است با اين حال يك تصوير زنده در خاطرات است (Truc 2011). بِ در يس سو ما خاطرات مكـانهـا را

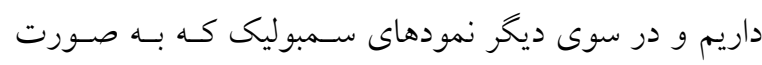
محملى براى (مكانهاى خاطرات)) عمـل مسى كنتــ كـه انـواع سادهتر از مكانها اما بىشك محكمتر و قوىتـر و مانـد مارتر از نوع قبلى هستند.

بنابراين خاطرات براى ماندگارى بيشتر بايد خودشـان را را

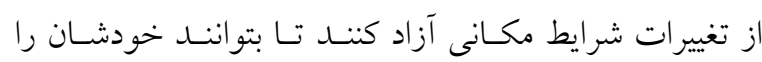
دربرابر تغيير يا نابودى حفظ كنند، با اين حال بايـــ بـه مكـان

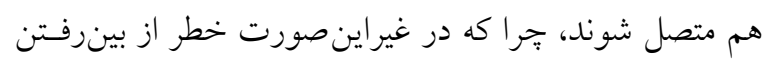

حفظ و حذف خاطرات جمعى بر مبناى مصالح سياسى عمـل كردهاند، كمتر راهى به جارجوب تعاملات شفاهى باز مى كنند

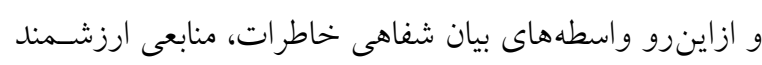

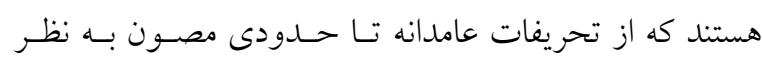

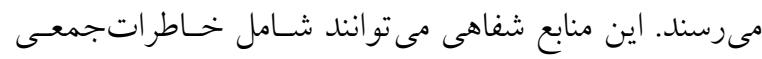
مردم عادى، اهل فن و سازند گان آثار معمارى، سـخنان ديخـر شاهدان و بهرهبرداران آثار و مانند آن باشند.

\section{ه. نسبت خاطرهُ جمعى و مكان} آميختخى احساسات و دريافتهاى بشرى بـا خـاطرات، گَــاه وجه تمايز مكان و فضا تلقى شدهاست (Hauge 2005). مكان موقعيت يكى رويداد است. نوربرى شولتز، بـا اشـاره بـه وازٔه

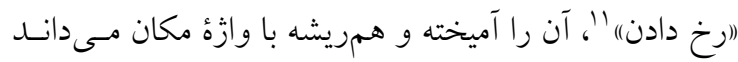
(Norberg-Schulz 1988). از نظر او يكى از شروط لازم براى

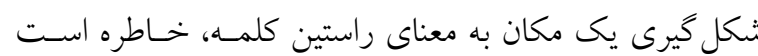

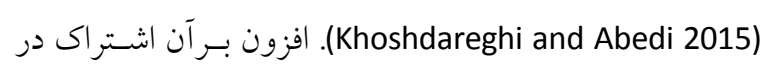
يكى مكان به معناى تعلق بـه يـك خـروه و در نتيجـه هويست

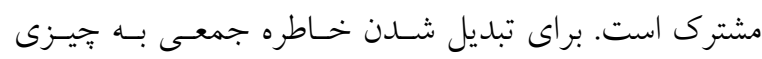
فراتر از يك تصوير ذهنى، بايد آنجه كه به ياد آورده مىشـود، در جايى رخ داده باشد. شرح دادن يكى واقعـه بــدون تصـور يك مكان، بسيار دشوار است. بنابراين ارتباط بين خاطرات ما

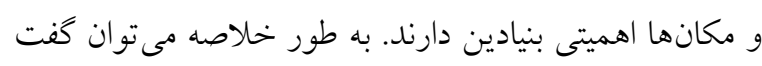
خاطرهاى كه فاقد مكان باشد به خطر عدم صحت مسى افتـد و بنابراين از بين مىرود (جدول ()).

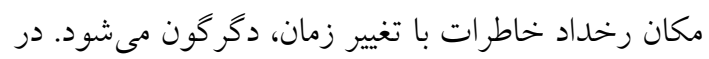
اين زمان خاطرات گروهى كه در نزديكسى مكـان مـورد نظـر 


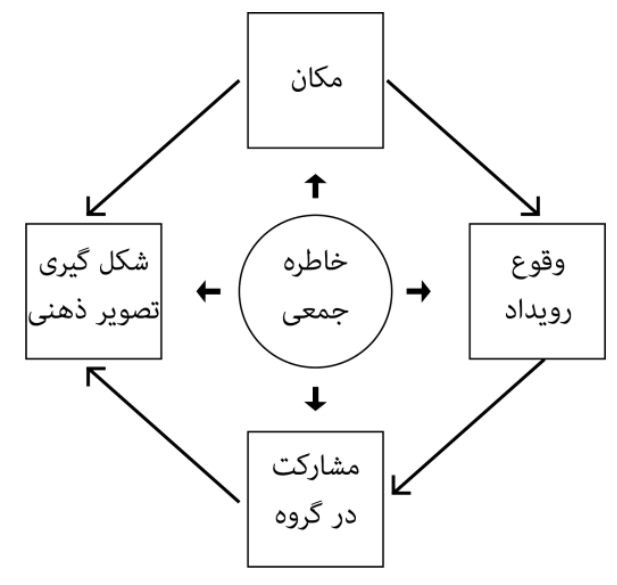

تصوير ז: نسبت خاطرةٔ جمعى، مكان، رويداد، گروه و تصوير ذهنى

Fig. 2: Collective memories, place, event, mental picture

كه معمولاً در رويداد خاطرات با شاهدان عينى رخ داده است و حركت دوم نهادينهسازى مكانهايى رسمى براى خـاطرات

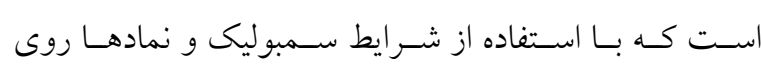

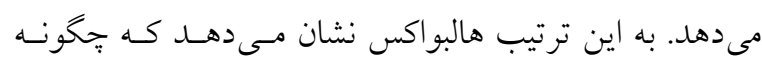

مكانهاى خاطرات از هيج ساخته مىشوند (تصوير ب).

\section{7. باز تاب مفهوم خاطره جمعى در} مطالعات تاريخ معمارى

مطالعـهُ جايخـاه مفهـوم خـاطره جمعسى در مطالعـات تـاريخ معمارى را مىتوان در دو شاخهُ كلى بررسى كـرد. در شـاخئ

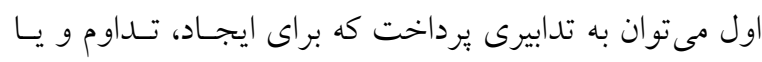

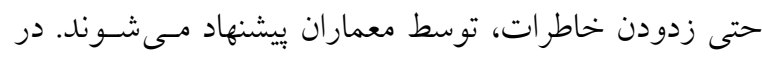

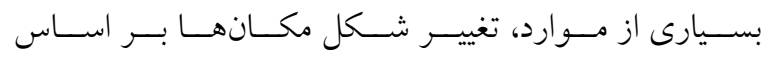

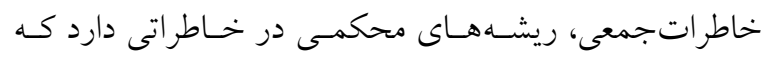

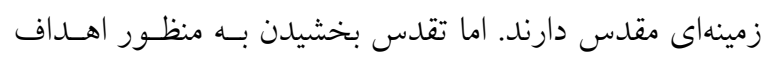
يادمانى، به تمام يا بخشى از فضاهاى عمومى، ايستخاهها و يــا

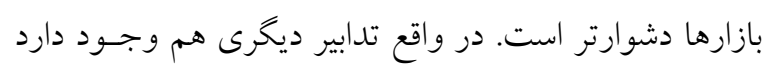
كه براى ايجاد مكانهاى خاطراتجمعى بـه كـار مسىرونـد و

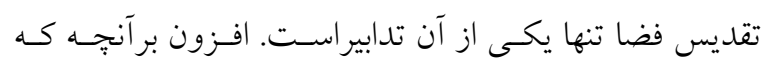

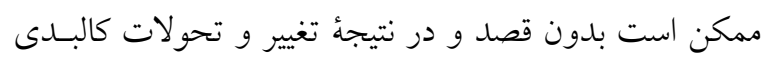

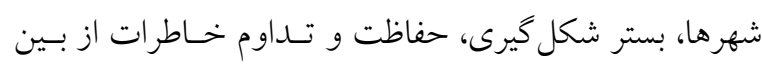
رود، اين احتمال وجود دارد كه ايسن اتفـاق عامدانـه هـم رخح دهد (Tarkashvand 2017). بنابراين اولين تـدبير، محوسـازى

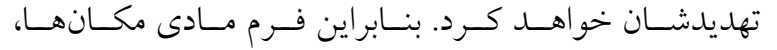
خاطراتجمعى را محدود مسىكنــد و تغييراتسى در آن ايجـاد

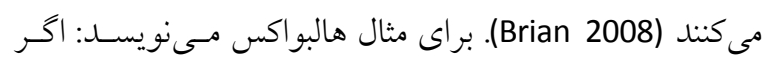
يكى خاطرة انجيلى در يكى غار روى داده باشد و اين غـار بـهـ

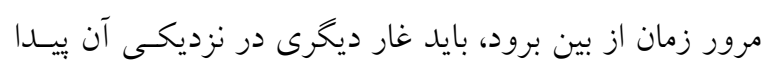

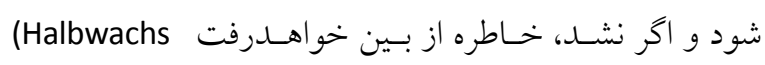
(1992. با اين حال، معناى اين موضوع وجود رابطـــ مسـتقيم

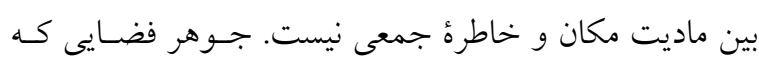
در آن خاطره جمعى رخ داده است، جوهرى بى جــان نيســ؛

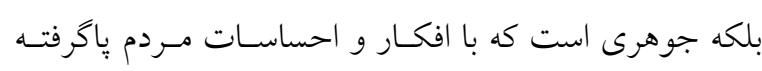
است. در اين نظريه، معنى فضا از مكانى از جيزها به فضـا بـهـ

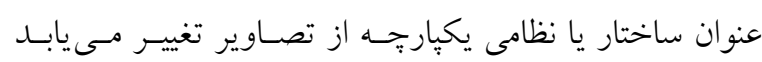

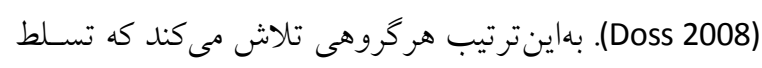

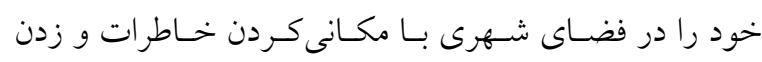

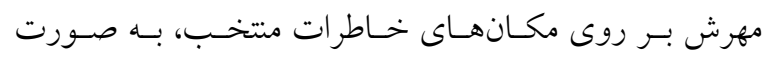
سمبوليك بيان كند. براساس آنجه كفته شد، كيفيت خاص ايجاد شده در يك دئل

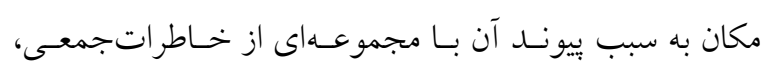
نوعى از احساس مالكيـت و حسى از تعلـق در آن مكـان را

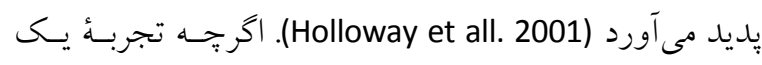
مكان به صورت فردى رخ مى دهد، تجارب مشـترى حاصـل از دستهبندىهاى اجتماعى و ويزگ كى هاى فـردى منـتج از ايـن دستهبندى هـا، در نهايـت بـه دريافـت و ذخيـره و ثبـت ايـن

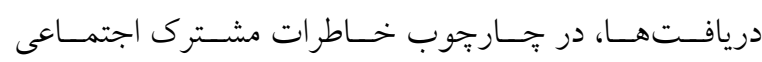
مى انجامد (Hague 2005). بـه عبـارتى بـا آنكـهـ منشـأ دوام و

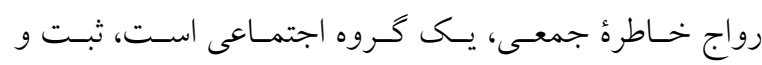

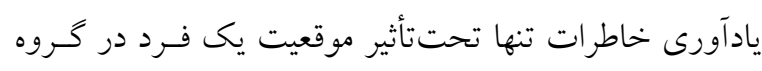

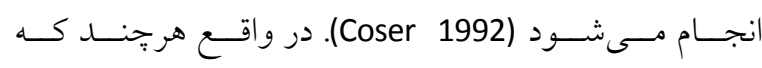

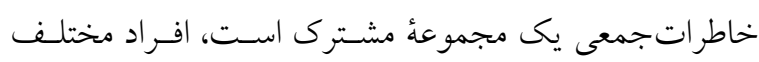

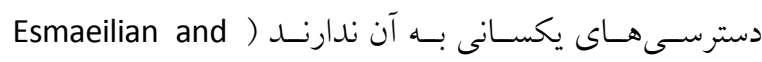
Ranjbar 2014 متضاد وجود دارد كه مورد توجه انديشمندان حافظهُ جمعى و رابطهاش با مكان است. حركت اول يادمانى سازى مكـانهـاى

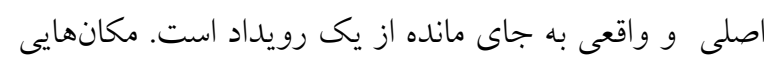


جاى مى ماند. معمارى، جون يك محصول فرهنكى در شـكل

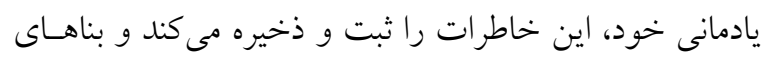
يادمانى محمل حضور خاطرات مىشـوند. بنـابر اين مسىتسوان حضور و ظهور خاطراتجمعى را در اين بناها جستجو كرد. افزون بر اين دو دسته، فضاهاى عمومى شهر كه محـل ديــار

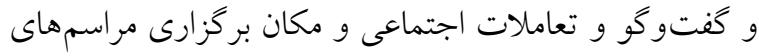

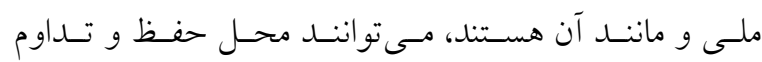

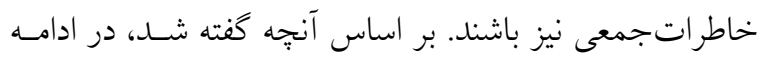

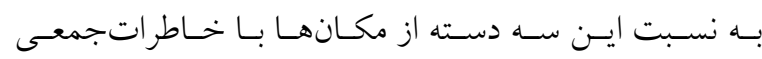
يرد اختهشدهاست.

\section{7- (. مطالعه درباره بناهاى مذهبى}

بناهاى مذهبى در حفظ و تداعى خاطراتجمعى نقشى ويـزّه

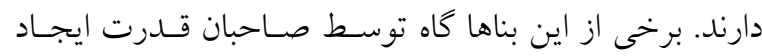

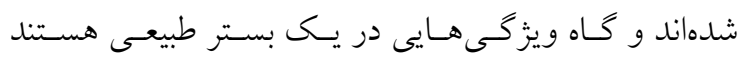

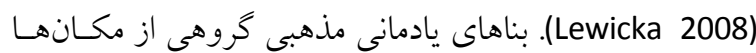

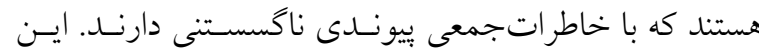

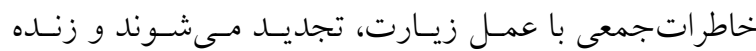

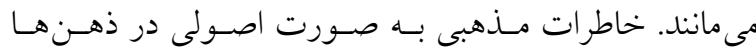

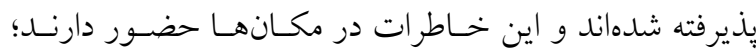
بناهاى يادمانى مذهبى، هم محل حفظ و احياى اين خـاطرات و هم مكانى براى آفرينش خاطرات جديد هستند.

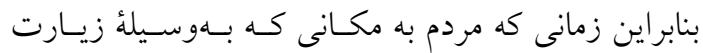
خاطره ذهنى در آن ايجاد شده اسـت، سـفر مسى كنــــ و كـاه تغييرات زيادى در آن مكان مشاهده مى كنند، سعى مى كنند كه

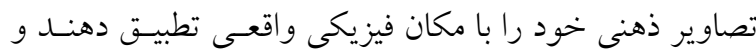

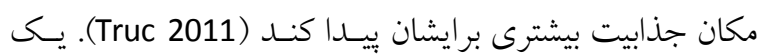

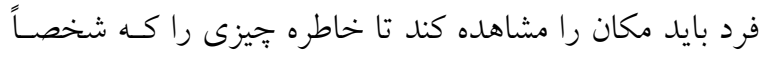

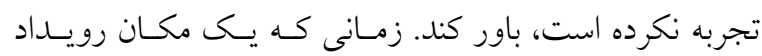

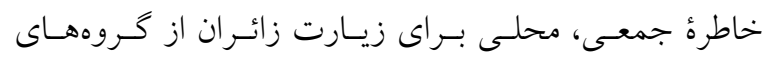

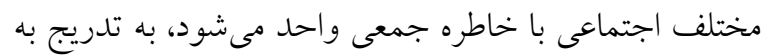

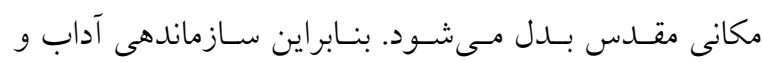

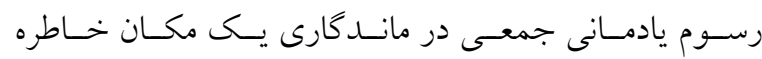

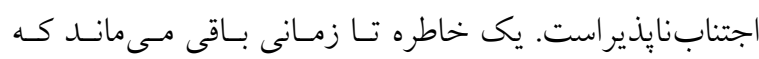

يا پِاكسازى است كه در آن تلاش مىشود كه محل واقعـه بـهـ

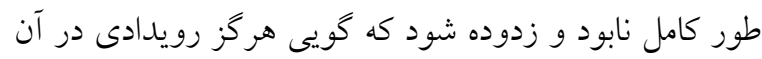
رخ نداده است (Margry 2010). در تــدبير دوم كـه (اصـلاح)"

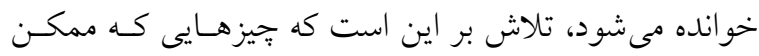

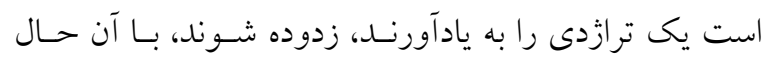

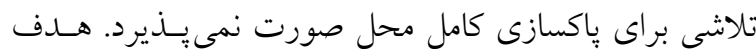

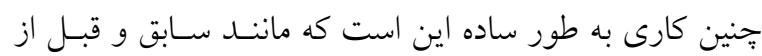

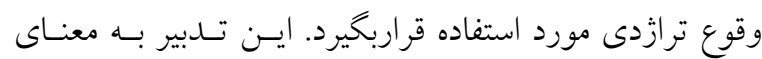

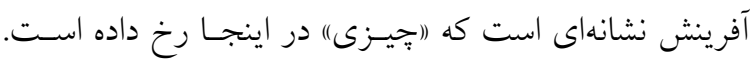

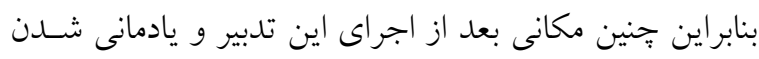

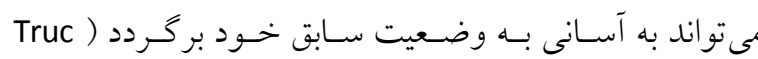

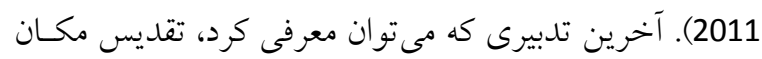

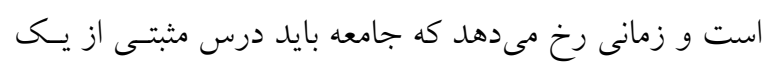

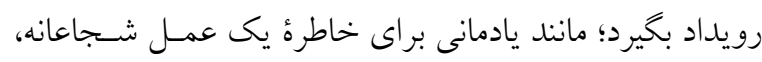
قربانى كردن خود براى جامعه و نمايش يكيارجگكى و اتحساد.

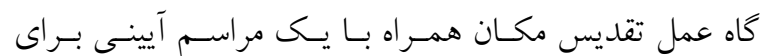
بازگشايى است و يكى جنبه از آيين عمومى به شمار مسىرود.

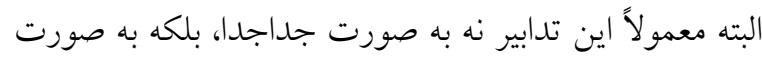

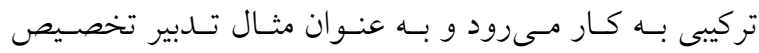

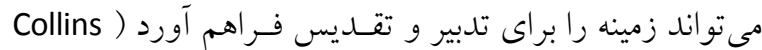
2004). افزون بر اين تدابير، در شاخهُ دوم مطالعات مسى تـوان

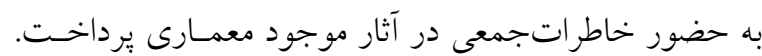

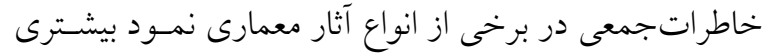

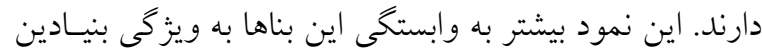

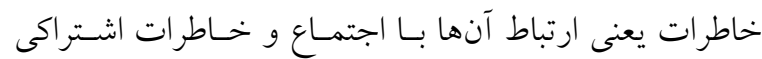

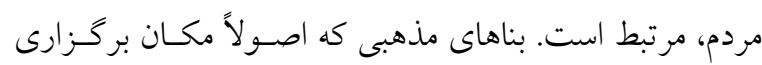

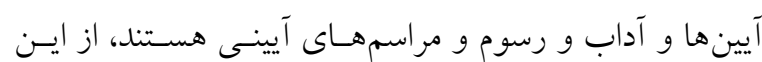

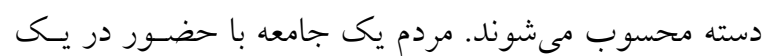

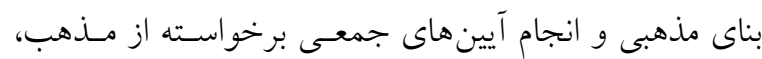

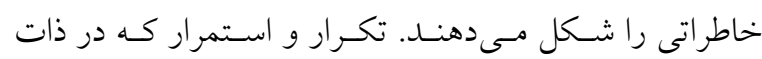

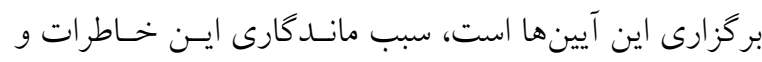

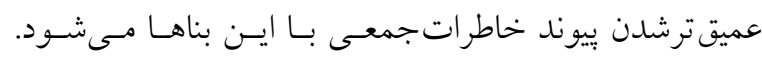

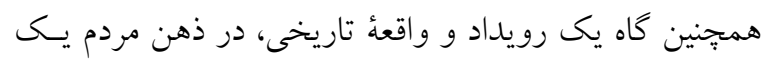

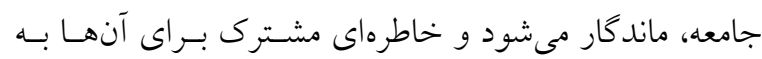


اشتراى كذاشته مسىشـود و بــه ايسن ترتيـب كسـانى كـه بـهـ خاطرات ديخران دسترسى دارند، مىتوانند خاطرات خودشان را دربارة همـان تجربسه، توسـعهدهـــ (Sas and Dix 2006). باينوجود براى حفظ و نخاهداشت خاطرات جمعى، آفرينش بناهاى يادمانى كه محمل خـاطرات هسـتند، يكسى از بهتـرين راهها است. همجنين اخر هــف از ايسن مطالعـات فهـم بهتـر

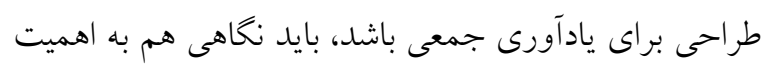

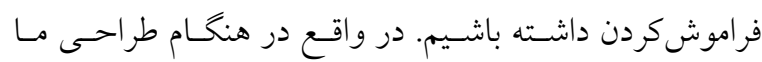

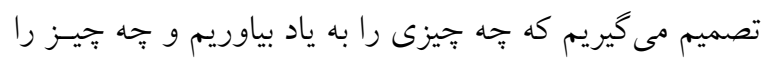
فراموش كنيم (Galloway 2006). به طور كلى، مطالعه دربـارة فضاهاى يادآورى خاطرات را مىتوان به دو دسته تقسيم كـرد

:(Iranmanesh and Amini 2013) 1- فضايى كه در آن يك رويداد تـاريخى اجتمـاعى رخ داده

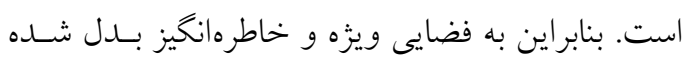

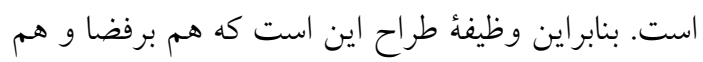
خاطرة آن تأكيد و آن را تشديد كند. r- آفرينش فضايى بــراى ايجـاد نشـاط و لـــت و آفـرينش

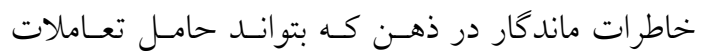

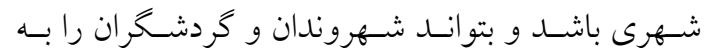
حضور در اين فضاها برانخيزاند.

\section{7-" - خاطره جمعى و شهر}

در ميان حوزههاى مختلف مطالعات معمارى، مطالعـه دربـاره

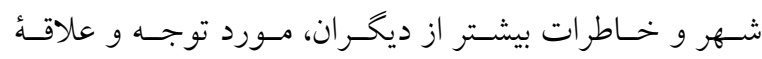
محققان بوده است. به طورى كه در ميان معماران مشهور آلدو

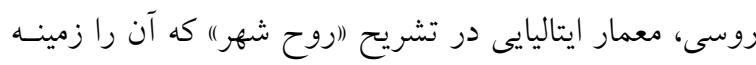
تعريف و بقاى هويت شهر مى داند، از اولين كسانى است كـه مفهوم خاطرة جمعى را وارد ادبيات مطالعات معمارى مى كند (Hasani Mianroudi et al. 2018) مىتوان كفت كه شهر خود خاطرة جمعسى مسردش اسـت و

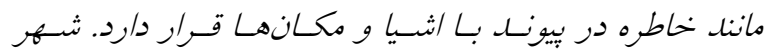
تجلىكساه خـاطرة جمعسى اسـت. بنسابراين رابطسه ميان /يـن تجلى گاه و شهرونالى تصور غالب شهر /ز معمارى و منظر را مى سازد. هنغامى كه مصنوعات مشخص به بخشى /ز خـاطره تبلديل مىشونله، تصوير جاديلى در ذهن بلديـار مسى شـود...
كروهى از مردم وجود داشته باشند كه اين خاطرات براى اين كروه، اهميت ويزهاى داشته باشد. اكر اين گروه از بين بروند و يا ارتباط با آن قطع شود، اخر اين افراد مكانهايى را كه قبلاً

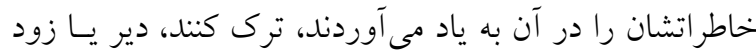
خاطرات آن مكانها هم از بين خواهدرفت. مكانى كـه ديخـر زائرانى را به خود جلب نمى كند يا هيج مراسم و آيينى در آن رخ نمىدهد، تنها نامى از (اخاطره جمعى)" به خود دارد.

\section{I-T. خاطره جمعى و آفرينث بناهاى يادمانى}

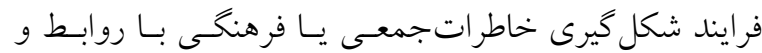
مفاهيم و شـرايط يبجيــداى درگيـر اسـت. در طـول تـاريخ، معمارى براى نشان دادن هويت كسانى كه در قـدرت هسـتند و آن جنبه هايى از هويت ملى كه گروه صاحب قـدرت مايـل است تا به ظهور بيايد، به كار مىرفته است و اين به رابطـهاى

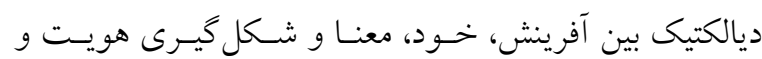
شهرسازى انجاميده است (Heidernreich 1995). درسالهـاى اخير بخشى فزاينده از ادبيات موضوع معمارى به رابطسه بـين معمارى و مسائل خـاطره و حافظهـ جمعسى و هويـت ملىى، مذهبى و قومى اختصاص يافتهاست. هويت همواره بـا مكـان فيزيكى مرتبط بوده است. ديد كاه غالب اين است كـه خـاطرة جمعى يا فرهنكى از طريق جيزها، تصاوير و بازنمودها ايجـاد

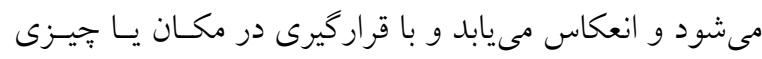
مشـخص ادارك مسىشـود و بنـابراين از اهميتسى بنيـادين در طراحى معمارى و طراحى شهرى برخوردار اسـت. خـاطرات جّه فردى وجّه جمعى، فهم تجارب كذشته و امكان يـاد گيرى

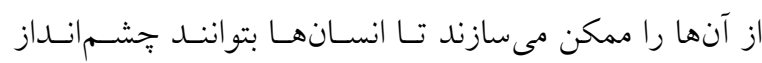

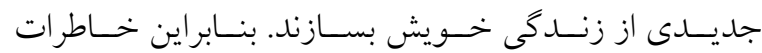

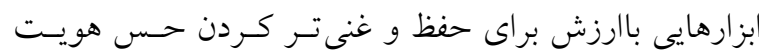
مردم است.

يكى از راههاى يشتيبانى بهتر براى يادآورى خاطرات مـا بيرونىكردن آنها، تسخير و ذخيره آنها است. امروزه فراينـد ذخيـرهسـازى و يـادآورى خــاطرات بـا تصـاوير ديجيتـال و مجموعههاى صدا و تصوير آسانتر شدهاست و اين امكانـات جديد خاطرات را در دسترستر كردهاند. زمانى كه خـاطرات به اشتراى كذاشته مى شوند، تجارب غنى همراه آنها هــم بــهـ

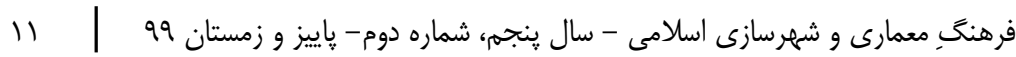




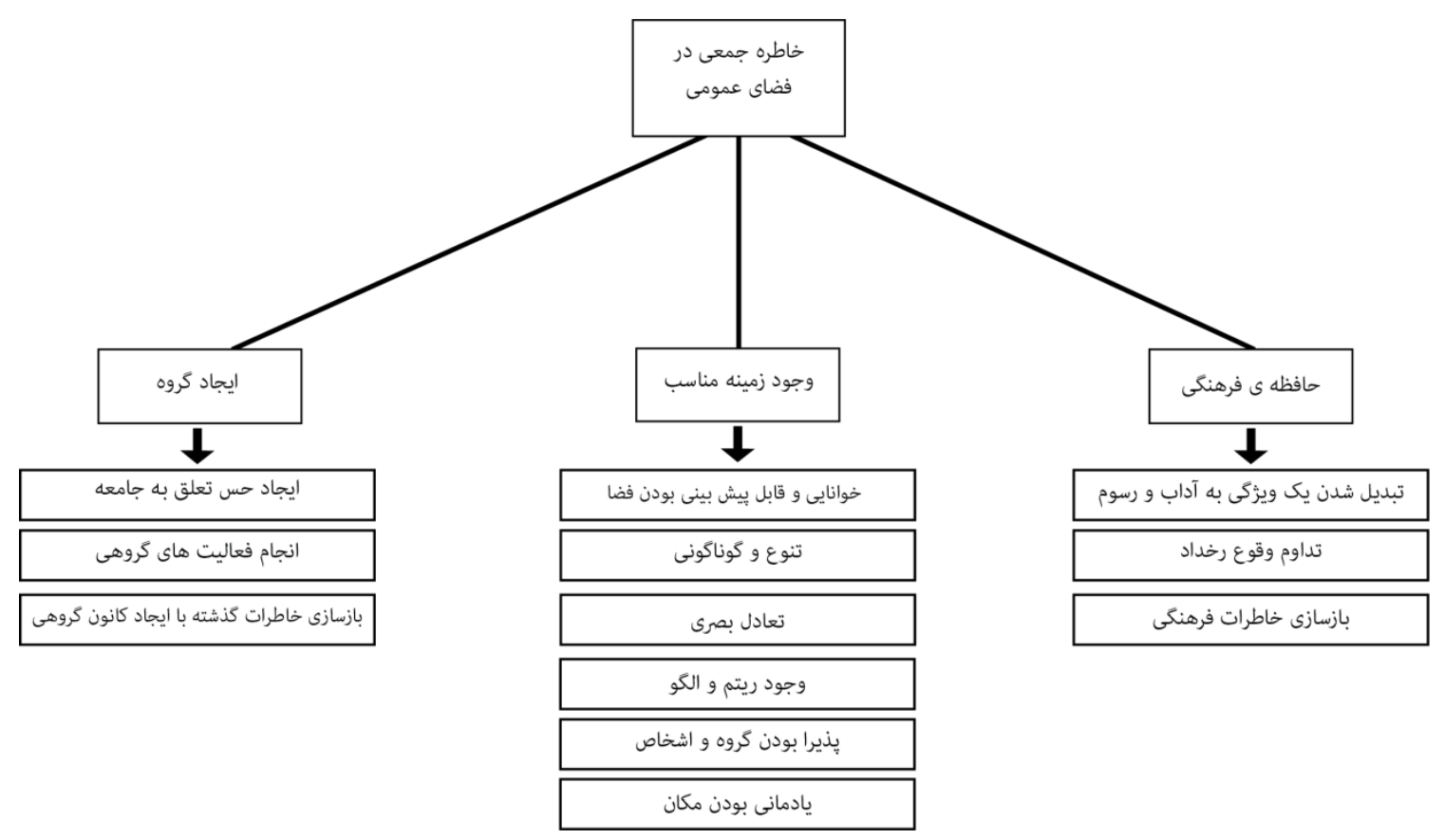

تصوير ب: خاطرة جمعى در فضاهاى عمومى

Fig. 3: Collective memories in the public spaces

تبديل شدن آن به يكى از آداب و رسوم اجتمـاعى، منجـر بـهـ

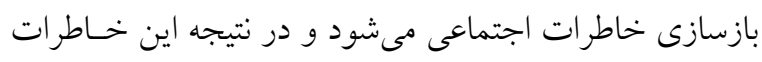
در حافظة فرهنكى يكى جامعه ماندكار مى شود. اين ماندكارى

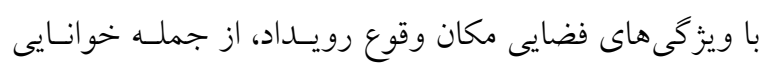

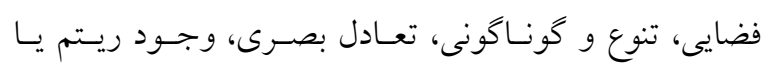

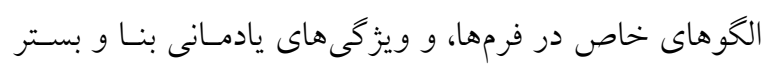

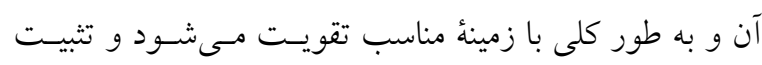

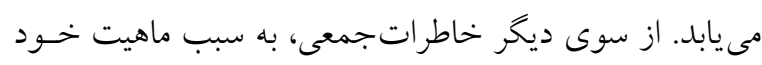

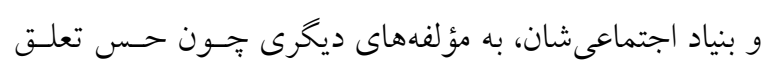
به كـروه اجتمـاعى، تشكيل كـانونهـاى اجتمـاعى و و انجـام

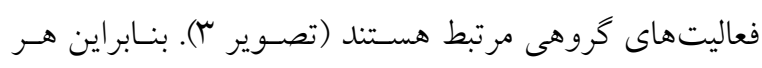

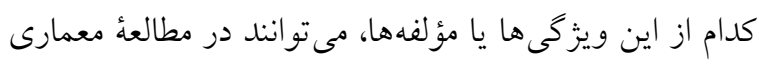
از مسير خاطراتجمعى، برجستهشـوند و مـورد توجـهـ ويـزّه

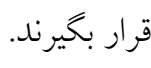

(Rossi 1982). فضاى شهرى بسترى است كه حيات مدنى در

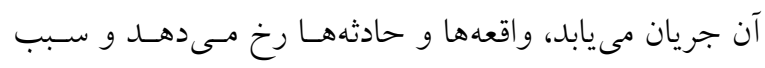

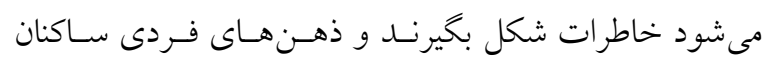

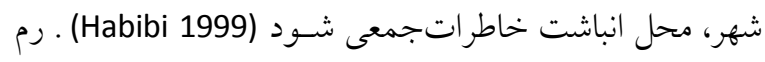

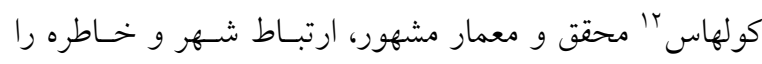
يك ارتباط ضرورى مى داند. از نظر او شهرى كه فاقد خـاطره

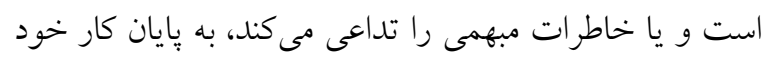

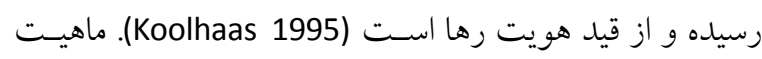

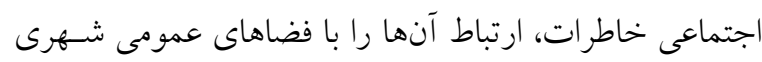

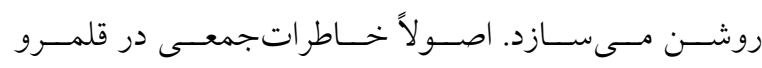

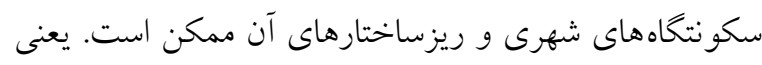

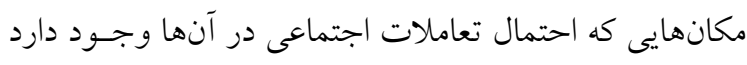
(Mirmoghtadaee 2009)

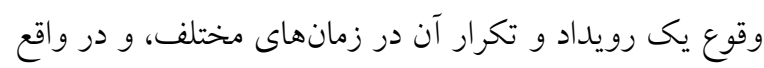

\section{نتيجه كَيرى}

خاطراتجمعى، خاطرات رخدادهايى هسـتند كـه درون يـى كروه اجتماعى رخ مى دهند و براى اعضاى آن گروه مشـترى 
بازتاب مفهوم خاطره جمعى در تاريخنخارى معمارى

مى توان با مطالعهُ خاطراتجمعى هم تصـوير روشـنتـرى از كـاركرد آنهـا يافـت و هـم وجـهـ نمـادين و معنـايىشـان را روشنتر كـرد. دسـته ديخــى از آثـار معمـارى كـه آنهـا را

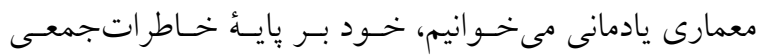

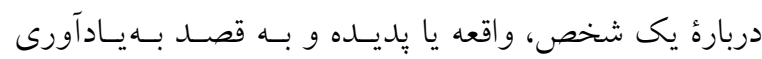

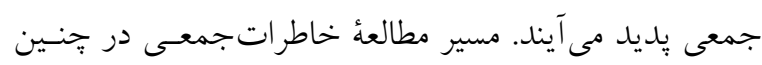

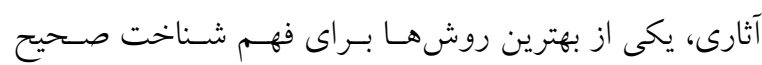
جنين آثارى است. مطالعهُ خاطراتجمعسى در ايسن دسـت از

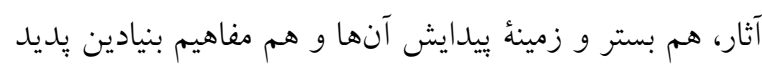

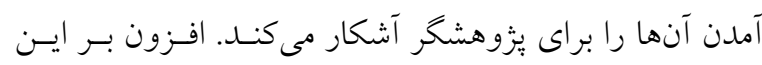

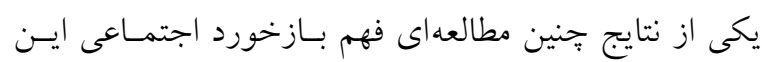

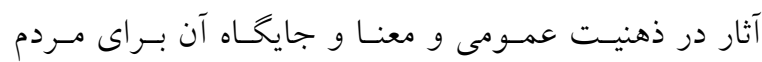

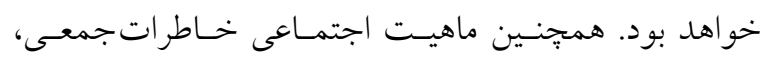
ارتباط آن را با فضاهاى شهرى كه محل رخدادهاى جمعى بهى همئ

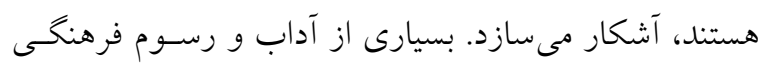

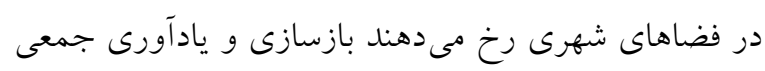
مندرج در حافظهُ فرهنكى در اين فضاها رخ مىدهد و البتـه وجود زمينههاى مناسب يادآورى و از آن جملـه خوانـايى و شفافيت فضاها، تعادل بصرى آنها و مؤلفههايى جهون ريستم

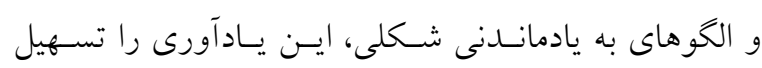

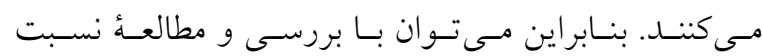

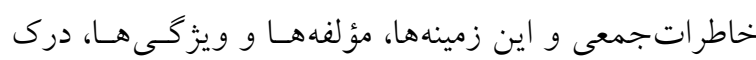
بهترى از معمارى اين فضـاها بـه دسـت آورد. همجنــين بـا مطالعهُ خاطراتجمعى احساس تعلـق بـهـ شـهر و احسـاس هويت و وابستكى به يك فرهنگ از زاويهاى مناسـب قابـل

$$
\text { فهم و شناسايى مى شود. }
$$

به نظر مىرسند. اين مفهوم در بنياد خــود، مـاهيتى اجتمـاعى دارد و با مكان بييوند خوردهاست. مكانها محل شكل گيـرى و همجنين دوام و ماندكارى خاطر اتجمعى هستند. بـراينمبنـا، مى توان از اين مفهوم براى مطالعات تاريخ معمارى هـم بهـره جست. خاطراتجمعى مانند تاريخ راوى كذشته هسـتند؛ امـا

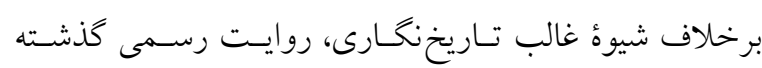

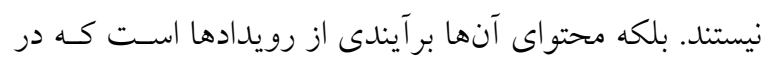

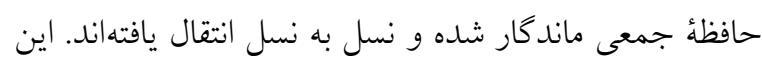

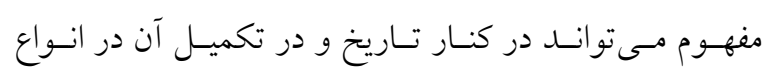

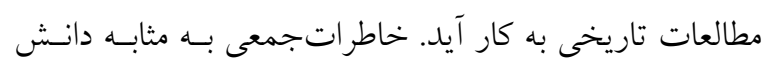

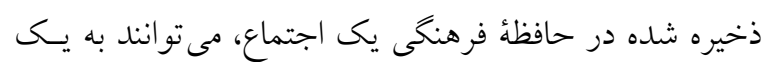

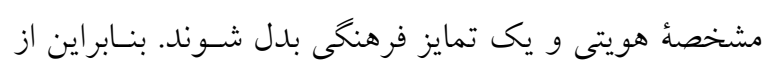

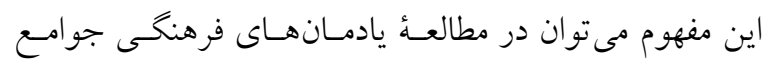

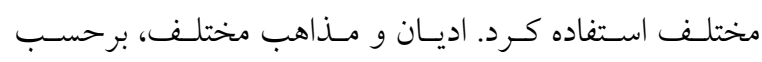

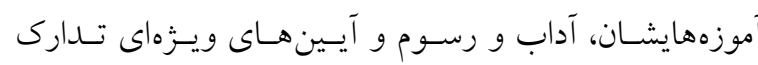
مى بينند. براين اساس خـاطراتجمعسى مـذهبى در فضـاهاى

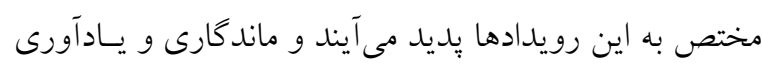

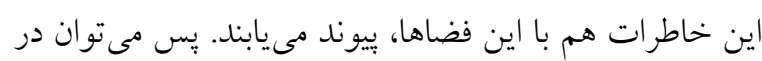

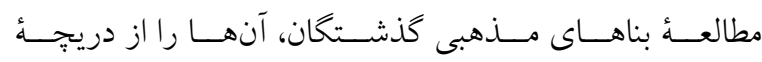
خـاطراتجمعسى هـــم مشـاهده كـرد. وقـوع يـــ رويــداد، شكل گيرى تصوير ذهنى از آن با مشاركت در يك گروه و در

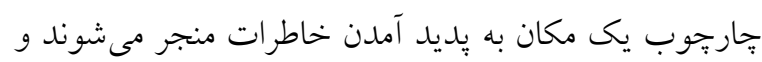

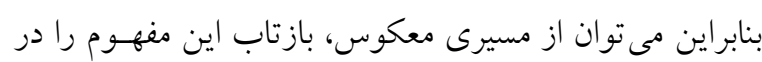

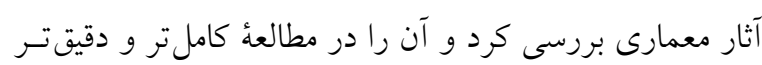
به كار بست. همجنين معناى آثار معمارى در ذهنيت مخاطبان

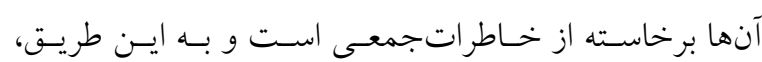

\section{بيىنوشتها}

1. Collective memories

2. Hugo Von Hofmannsthal

3. Maurice Halbwaches

4. Emile Durkheim

5. Henry Bergson

6. The Social Frameworks of Memory

7. Social Representations

8. La Topographie Legendaire des Evangiles en Terre Sainte

9. Memoire Sociale

10. Jacques Le Goff

11. Take Place

12. Rem Koolhaas 


$$
\begin{aligned}
& \text { فهرست منابع }
\end{aligned}
$$

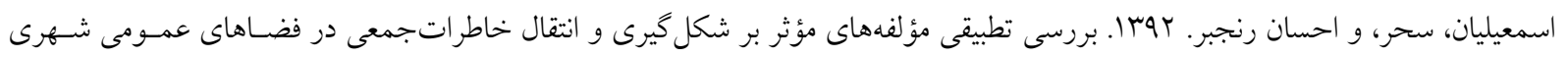

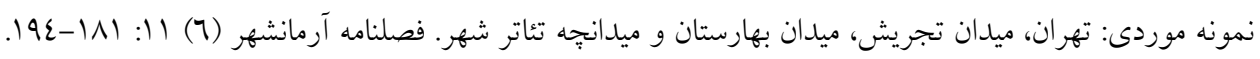

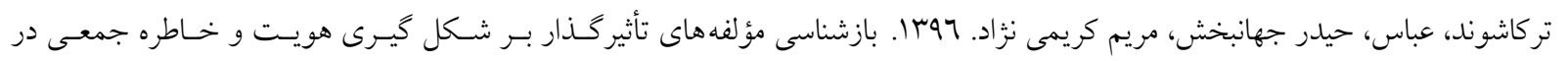

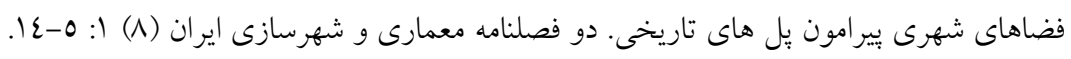

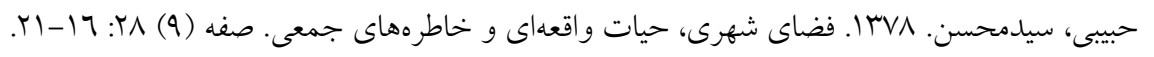

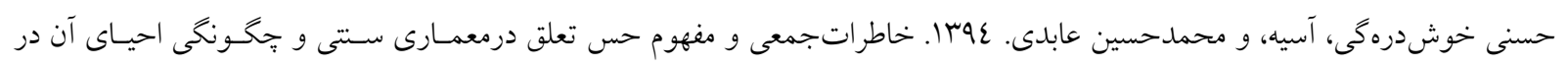

$$
\begin{aligned}
& \text { معمارى امروز. همايش ملى معمارى و شهرسازى ايرانى اسلامى: رشت مان. } \\
& \text { حسنى ميانرودى، نسيم، حميد ماجدى، زهر اسادات سعيده زرآبادى، و يوسفعلى زيارى. }
\end{aligned}
$$

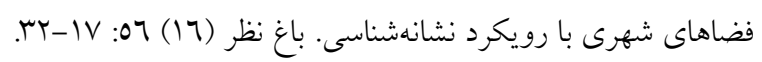

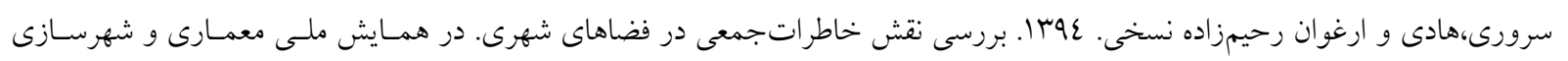

$$
\begin{aligned}
& \text { هويت گرا، مشهد. }
\end{aligned}
$$

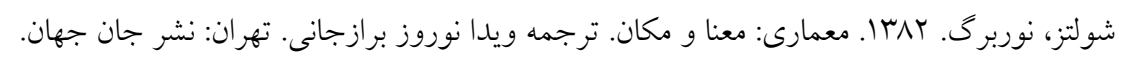

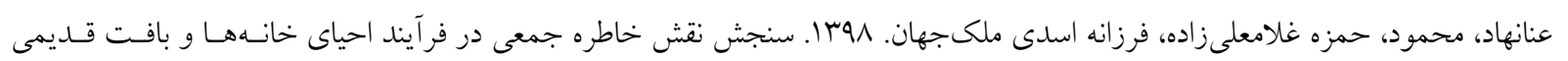

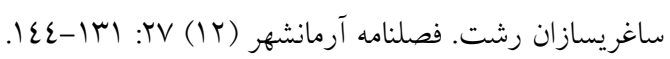

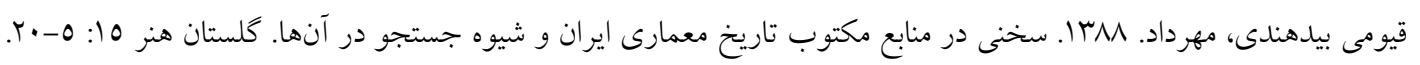

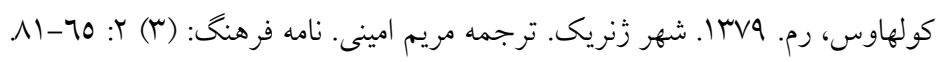

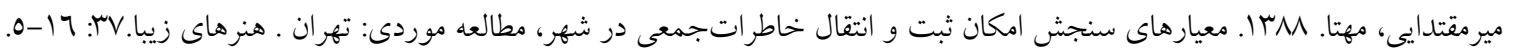

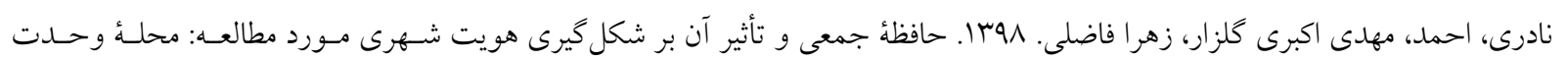

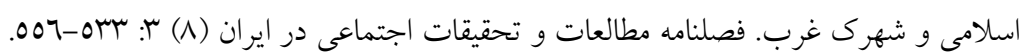

Ananahad, Mahmoud, Hamzeh Gholam Alizadeh, and Farzaneh Asadi MalekJahan. 2019. Assessing the Role of Collective Memory in the Process of Rasht's Saqarisazan Houses and Old Texture Revitalization. Armanshar Journal of Architecture and Urban Development 27(12): 131-144. [In Persian].

Assmann, Jan. 1995. Collective Memory and Cultural Identity. New German Critique.65:125-133.

Brian, E. 2008. Portée du lexique halbwachsien de la mémoire. In: Halbwachs, M (ed.) La Topographie Légendaire des Evangiles en Terre Sainte. Paris: PUF, 113-145.

Burkett, Christopher Paul. 2009. Homiletics as Mnemonic Practice: Collective Memory and Contemporary Christian Preaching With Special Reference to the Work of Mauric Halbwaches (PhD Thesis), University of Liverpool, 63-69.

Carpenedo, Manoela. 2017. Collective memory in the making of religious change: the case of 'emerging Jews' followers of Jesus. Religion 48(1): 83-104.

Collins, Randall. 2004. Interaction Ritual Chains. Princeton, NJ: Princeton University Press. Dayan

Coser,L.A. 1992. The revival of the sociology of culture:The Case of collective memory. Sociological Forum 7(2):365-373.

Doss, Erik. 2008. The Emotional Life of Contemporary Public Memorials: Towards a Theory of Temporary Memorials. Amsterdam: Amsterdam University Press.

Esmaeilian, Sahar, and Ehsan Ranjbar. 2014. Finding Main Effective Factors of Creating and Transition of Collective Memory in Urban Public Spaces, Case Study: Tehran: Tajrish Square, Baharestan Square, and Plaza City Theater. Armanshar Journal of Architecture and Urban Development 11(6): 181-194. [In Persian].

Eyerman R. 2002. Cultural trauma: Slavery and the Information of African American Identity, Cambridge: Cambridge University Press.

Galloway,Anne. 2008. Collective Remembering and the Importance of Forgetting, a Critical Design Challenge. Carleton: Carleton University.

H.Hutton,Patrick. 1988. Collective Memory and Collective Mentalities: The Halbwachs-Aries Connection, Historical Reflections 15(2):311-322.

Habibi, Seyed Mohsen. 1999. Urban Space, Events, and Collective memories. Soffe 28(9): 16-21. [In Persian].

Hague, Cliff. 2005. Planning and Place identity. In Place, identity, participation and planning. Ed. Cliff Hauge and Paul Jenkins. London: Routledge. 
بازتاب مفهوم خاطرة جمعى در تاريخنخارى معمارى

Halbwachs,M. 1992. On Collective Memory.Trans.and ed.L.A.Coser. Chicago: University of Chicago Press.

Hasani Khoshdareghi, Asiyeh, and Mohammad Hoseyn Abedi. 2015. Collective memories and the concept of sense of belonging in traditional architecture and how to revive it in today's architecture. In National Conference on Iranian Islamic Architecture and Urbanism: Rasht, Iran. [In Persian].

Hasani Mianroudi, Nasim, Hamid Majedi, Zahra Sadat Saeide Zarabadi, and Yousefali Ziari. 2018. Exploring Concept of Collective Memory and its Retrieval in Urban Areas with Semiotic Approach (Case study: Hasan-Abad square). BAGHE-NAZAR 56 (16): 17-32. [In Persian].

Heidenreich,Luise. 1995. Collective Memory, Identity and Place Making In Reunified Berlin. 10-15.

Hirst, William, and Gerald Echterhoff. 2012. Remembering inConversations: The SocialSharing and Reshapingof Memories. Annual Review of Psychology 63: 55-79.

Holloway, Lewis and Hubbard Phil.2001. People and Place. London: Pearson Education .

Iranmanesh,Nasrin, and Elham Amini. 2013. Creating Collective Memories in Urban Spaces of Iran. Real Corp 2013: 195-203.

J. Savelsberg, Joachim, Ryan D. King. 2007. Law and Collective Memory. Annual Review of Law and Social Science 3: 189211.

Jaisson, M .2008. Mémoire collective et espace social. In: Halbwachs, M La Topographie Légendaire des Evangiles en Terre Sainte. Paris: PUF, 73-97.

K. Olick, Jeffrey, and Joyce Robbins.1998. Social Memory Studies: From "Collective Memory" to the Historical Sociology of Mnemonic Practice. Annual Review of Sociology 24: 105-140.

K.Olick,Jeffrey, ,Vered Vinitzky Seroussi, and, Daniel Levy. 2011. The Collective Memory Reader, Oxford: Oxford University Press .

Koolhaas, Rem. 1995. Generic City. Translated by Maryam Amini. Name Farhangh 2 (3): 65-81.

Le Goff J. 1992. History and Memory. New York: Columbia Univ. Press.

Lewicka, Maria. 2008. Place attachment, place identity, and place memory: restoring the forgotten city past. Journal of Environmental Psychology 28(3): 209-231.

Mirmoghtadaee, Mahta. 2009. Criteria for measuring the possibility of formation, registration and transfer of collective memories in the city, Case study: Tehran. Journal of fine arts 37: 5-16. [In Persian].

Misztal, Barbara. 2003. Durkheim on Collective Memory. Journal of Classical Sociology 3(2): 123-143.

Naderi, Ahmad, Mahdi Akbari Golzar, Zahra Fazeli. 2019. Collective Memory and Its Impact on the Formation of Urban Identity (Case Study: Vahdat-e-Islami and Shahrak-e-Gharb). Quarterly of Social Studies and Research in Iran: 3(8): 533-556. [In Persian].

Norberg-Schulz, Christian. 1988. Architecture, Meaning and Place. Translated by Vida Norouz Barazjani. Tehran: Jane Jahan. Press . [In Persian].

Paez, Dario, Besabe, Nekane, and Gonzalez, Jose Luis .1997. Social processes and collective memory: a crosscultural approach to remembering political events. In: Collective Memory of Political Events, Social Psychological Perspectives, Ed. James W. Pennebaker, Dario Paez \& Bernard Rimé Mahwah. NJ: Lawrence Erlbaum.

Qayyumi-Bidehendi, Mehrdad. A speech in written sources of The History of Iranian Architecture and the Way they Are Searched .2009. Golestan-E-Honar 15: 5-20. [In Persian].

Rico, p. 1995. Forgotten Historical Memory. Journal of talks 8:49. [In Persian].

Rossi, Aldo. 1982. The Architecture of the City, Massachusett: The Institute for Architecture and Urban Studies and the Massachusett's Institute of Technology.

Sarvari, Hadi, and Arghavan Rahimzadeh Nasakhi. 2015. The Role of Collective Memories in Urban Spaces. In National Conference on Identity-Oriented Architecture and Urbanism, Mashhad, Iran. [In Persian].

Sas, Gorina, and Alan Dix .2006. Designing for Collective Remembering. Lancter: Lancter University.

Schieder T. 1978. The role of historical consciousness in political action. Hist. Theory 17:1-18.

Siew-wai lim, William. 2000. Memories and urban places, City 4(2): 270-277.

Tarkashvand, Abbad, Heydar Jahanbakhsh, and Maryam Kariminejad. 2017. Recognition of Components Affecting the Formation of Identity and Collective Memory Around Historic Bridges (Case Study: Langroud City). Journal of Iranian Architecture \& Urbanism 1 (8): 5-14. [In Persian].

Truc,Gerome. 2011. Memory of Places and Places of Memory: For a Halbwachsian Socio-Ethnography of Collective memory. International Social Science Journal 62:147-159

Urbaniak, Jakub. 2015. Religion as memory. Theological Studies 71(3.(

Zeuler, Lima, and Vera M. Pallamin .1998. Architecture and Memory: References in Contemporary Culture. In ACSA West Central Region Conference. Washington University, Saint Louise. 1-11. 